\title{
Article \\ Efficient Separation of Silicon and Vanadium by Sodium Roasting-Water Leaching from Vanadium Slag and $\mathrm{CaV}_{2} \mathrm{O}_{6}$ Preparation
}

\author{
Changqing Li (D, Haichao Zhang, Ma Tao, Xufeng Wang, Hang Li, Yungang Li * and Ying Tian *
}

Citation: Li, C.; Zhang, H.; Tao, M.; Wang, X.; Li, H.; Li, Y.; Tian, Y.

Efficient Separation of Silicon and Vanadium by Sodium Roasting-Water Leaching from Vanadium Slag and $\mathrm{CaV}_{2} \mathrm{O}_{6}$ Preparation. Crystals 2021, 11, 255. https://doi.org/10.3390/ cryst11030255

Academic Editor: Brahim Benyahia

Received: 16 February 2021

Accepted: 1 March 2021

Published: 4 March 2021

Publisher's Note: MDPI stays neutral with regard to jurisdictional claims in published maps and institutional affiliations.

Copyright: (c) 2021 by the authors. Licensee MDPI, Basel, Switzerland. This article is an open access article distributed under the terms and conditions of the Creative Commons Attribution (CC BY) license (https:// creativecommons.org/licenses/by/ $4.0 /)$.
Key Laboratory of Ministry of Education for Modern Metallurgy Technology, College of Metallurgy and Energy, North China University of Science and Technology, 21\# Bohai Road, Caofeidian Xincheng, Tangshan 063210, China; lcq15176623530@163.com (C.L.); zhanghaichao@stu.ncst.edu.cn (H.Z.); matao2011@sina.com (M.T.); wxf7382@163.com (X.W.); lihang6147@126.com (H.L.)

* Correspondence: lyg@ncst.edu.cn (Y.L.); tianying518@163.com (Y.T.)

Abstract: Calcium vanadate $\left(\mathrm{CaV}_{2} \mathrm{O}_{6}\right)$, a new product of vanadium precipitation, was obtained from vanadium slag by sodium roasting-water leaching and calcium precipitation. The separation behavior of vanadium and silicon in vanadium slag during sodium roasting and water leaching was systematically studied, and micro-morphology and valence migration behavior of vanadium and Fe in vanadium slag, roasting slag, and residue were revealed. The $\mathrm{Na}_{2} \mathrm{CO}_{3}$ was added to the vanadium slag at $20 \%$ mass fraction, roasted at $790{ }^{\circ} \mathrm{C}$, and kept for $120 \mathrm{~min}$, the roasted sample was added to the deionized aqueous solution with a liquid-solid ratio of (L/S) $5 \mathrm{~mL} / \mathrm{g}$, and then heated at $90{ }^{\circ} \mathrm{C}$ for $60 \mathrm{~min}, 89.54 \%$ vanadium and $1.96 \%$ chromium were extracted. Sodium carbonate tends to combine with vanadium to form sodium vanadate, while silicon is easy to combine with $\mathrm{Fe}$ and $\mathrm{Na}$ to form acmite $\left(\mathrm{NaFeSi}_{2} \mathrm{O}_{6}\right)$. When the molar ratio of $\mathrm{N}(\mathrm{Ca} / \mathrm{V})$ is 0.6 and $\mathrm{CaO}$, is added to adjust the $\mathrm{pH}$ of vanadium leaching solution to $6.7 \pm 0.1$ and precipitate $90 \mathrm{~min}$ at $90^{\circ} \mathrm{C}$, vanadium is precipitated in the form of $\mathrm{CaV}_{2} \mathrm{O}_{6}$ with a purity of $95.69 \%$, under these conditions, the precipitation ratio is $95.03 \%$.

Keywords: separate; vanadium slag; calcium vanadate; sodium roasting; kinetics

\section{Introduction}

Vanadium is a strategic rare metal element. Because of its high melting point, tensile strength, hardness, and fatigue strength, vanadium is almost all used in the field of black or non-ferrous alloys [1-7]. It is difficult for vanadium to exist alone in nature. Vanadium is mainly symbiotic with other minerals or occurs in vanadium-titanium magnetite. Vanadium-titanium magnetites are smelted in a blast furnace to obtain vanadium-bearing hot metal, and then vanadium is oxidized into the slag phase to obtain vanadium slag and semi-steel [8]. As a result, vanadium in vanadium titanomagnetite is enriched into vanadium slag.

At present, the main method of extracting vanadium from vanadium slag to prepare vanadium oxide is sodium roasting of vanadium slag-water leaching treatment-ammonia precipitation of vanadium-ammonia. The process mainly uses $\mathrm{NaCl}, \mathrm{Na}_{2} \mathrm{CO}_{3}$ and $\mathrm{NaOH}$ as sodium salt additives, roasting in an oxygen atmosphere at high temperature, so that the trivalent vanadium and tetravalent vanadium in vanadium slag are converted into pentavalent soluble sodium vanadate [9]. After water leaching, the supernatant of sodium vanadate is obtained by removing impurities, and then ammonium vanadate is precipitated by ammoniation. Vanadium pentoxide was obtained after calcination. This method of extracting vanadium, which is widely used at present, has the problem of high energy consumption and polluting gases such as $\mathrm{Cl}_{2}, \mathrm{NH}_{3}$, and so on [10]. It is worth noting that there is a high content of silicon in vanadium slag. After sodium roasting-water leaching of vanadium slag, only a little silicon is leached, which can effectively achieve 
the purpose of separating vanadium from silicon. However, there are few studies on the mechanism of phase transformation, valence migration, and difficult leaching of silicon in the whole process, and the leaching behavior of silicon has not been studied, which only stays at the empirical level, therefore, it is of great significance to study and understand the leaching behavior of silicon for industrial production. By studying the leaching behavior of silicon, we can guide the practice and determine the best experimental conditions under the condition of the highest yield of vanadium. To achieve the purpose of minimizing the leaching of impurity silicon.

The roasted clinker obtained by sodiumization of vanadium slag is leached with water to obtain a sodium vanadate solution. Ammonium salt precipitation method is mainly used to separate sodium vanadate and vanadium, that is, $\left(\mathrm{NH}_{4}\right)_{2} \mathrm{SO}_{4}$ or $\mathrm{NH}_{4} \mathrm{Cl}$ solution reacts with sodium vanadate solution to form ammonium metavanadate or ammonium polyvanadate precipitation with low solubility $[11,12]$. According to the $\mathrm{pH}$ value of the solution during precipitation, the ammonium salt precipitation method can be divided into weak basic ammonium salt precipitation method, weak acid ammonium salt precipitation method, and acid ammonium salt precipitation method. The weak basic ammonium salt precipitation method needs to adjust the $\mathrm{pH}$ value of the solution to 7.5-8.5, and the vanadium in the solution is precipitated in the form of $\mathrm{NH}_{4} \mathrm{VO}_{3}$, but because of the high solubility of ammonium metavanadate, the vanadium content in the residual vanadium solution is up to $1-2.5 \mathrm{~g} / \mathrm{L}$ [13]. The weakly acidic ammonium salt precipitation method requires that the $\mathrm{pH}$ value of the solution be 6 and vanadium precipitates in the form of decavanadate, but the chemical combination of alkali metal ions and decavanadate leads to the loss of vanadium in the subsequent roasting process [14]. The $\mathrm{pH}$ value of vanadium solution precipitated by acidic ammonium salt should be adjusted to 2-2.2, and vanadium forms ammonium hexavanadate precipitate. the quality of the vanadium product is good and the precipitation rate of vanadium is high. However, there are still the following problems in this process: first, a large amount of high ammonia nitrogen vanadium precipitation wastewater is produced, and the treatment cost is high; second, the potassium and sodium content in the prepared ammonium polyvanadate is high, in the subsequent vanadium-nitrogen alloy smelting process, sodium and potassium oxides are reduced and converted into sodium and potassium vapors, which easily react with refractory materials to bond and corrode the refractory materials, block the dust removal flue, and shorten the life of the furnace lining and furnace age; third, ammonium polyvanadate as a primary raw material for the production of other vanadium-containing chemical products, its sulfur, potassium, and sodium impurity content has an impact on the rear purification process. Precipitating calcium vanadate can avoid the problem of wastewater in the process of producing vanadium oxide. after further treatment of calcium vanadate, ammonium polyvanadate with lower content of potassium and sodium can be produced. at the same time, calcium vanadate, as an important intermediate product of vanadium, can provide raw materials for the preparation of ferrovanadium [15] and biomedical medicine [16].

In previous studies, calcium precipitation of vanadium is mainly used to remove low concentration vanadium impurities in high concentration sodium chromate solution. There are few reports on the preparation of $\mathrm{CaV}_{2} \mathrm{O}_{6}$ by high concentration calcium precipitation of vanadium, mainly because calcium oxide is mostly carried out under alkaline conditions during vanadium precipitation. Under these conditions, calcium salt is easily hydrolyzed to form calcium hydroxide, resulting in the decrease of effective calcium concentration in the solution, resulting in poor utilization of calcium salt. Therefore, the double dose consumption of calcium oxide will be caused during the precipitation of vanadium, which is usually about 10 times of the theoretical calculation consumption, which is also the reason why calcium salt is rarely used to precipitate vanadium with high concentration, so to inhibit the hydrolysis of calcium salt and increase the concentration of available calcium in the solution, we propose to prepare calcium metavanadate by precipitation of vanadium under weak acid conditions. 
In this paper, the leaching separation of silicon and vanadium from vanadium slag was systematically studied based on the technology of sodization calcination and aqueous leaching. The roasting leaching conditions were optimized by a single factor experiment. $\mathrm{CaV}_{2} \mathrm{O}_{6}$ was further prepared by precipitation of vanadium with $\mathrm{CaO}$.

\section{Experiments}

\subsection{Materials}

Vanadium slag came from Chengde (Hebei, China). Its composition is shown in Table 1. Other chemicals used in the whole process such as $\mathrm{Na}_{2} \mathrm{CO}_{3}$ and $\mathrm{CaO}$ were all of analytical grade. All of the solutions during the leaching process and analysis of vanadium content were produced with deionized water. It can be seen from Table 1 that the content of silicon dioxide is high, and soluble sodium salt is easy to form during sodium roasting. Therefore, attention must be paid to the content of silicon in the leaching solution.

Table 1. Chemical composition ( $\mathrm{wt} \%$ ) of vanadium slag in Chengde Iron and Steel Co.

\begin{tabular}{cccccccccc}
\hline Composition & $\mathrm{TFe}$ & $\mathrm{V}_{\mathbf{2}} \mathrm{O}_{5}$ & $\mathrm{SiO}_{2}$ & $\mathrm{TiO}_{2}$ & $\mathrm{CaO}$ & $\mathbf{M g O}$ & $\mathrm{Cr}_{2} \mathrm{O}_{3}$ & $\mathbf{M n O}$ & $\mathbf{P}_{2} \mathrm{O}_{5}$ \\
\hline Vanadium slag & 45.61 & 9.88 & 16.51 & 12.53 & 2.89 & 3.24 & 1.17 & 7.24 & 0.93 \\
\hline
\end{tabular}

\subsection{Sodium Roasting}

Mix a certain proportion of $\mathrm{Na}_{2} \mathrm{CO}_{3}(16-24 \%)$ with vanadium slag $(<74 \mu \mathrm{m})$ evenly, feed the mixture into the muffle furnace, heat up from room temperature to the experimental set temperature $\left(710^{\circ} \mathrm{C}-870{ }^{\circ} \mathrm{C}\right)$ at a heating rate of $10^{\circ} \mathrm{C} / \mathrm{min}$, and then kept for 30-150 min. When heating, the muffle furnace door is kept in a semi-closed state and sufficient oxygen is kept in the muffle furnace. At the end of the experiment, the roasted samples are cooled to room temperature, and then ground and sifted into powders for analysis and leaching experiments.

\subsection{Water Leaching}

First of all, a predetermined amount of deionized water is added to a flask with three necks, and the water in the flask with three necks is heated to a preset temperature under the action of a constant temperature water bath pot (50 to $99{ }^{\circ} \mathrm{C}$ ). To prevent the evaporation of water, the flask with three necks are connected with a reflux condenser. After the temperature reaches the preset temperature, the roasted clinker is added to the three-port flask (solid-liquid ratio 2 to $7 \mathrm{~mL} / \mathrm{g}$ ), and then start the stirring device (300 rpm) to make the roasted clinker fully leach for a certain time (20-70 $\mathrm{min})$, then sample, wash and detect, and analyze the content of vanadium and silicon in the leaching liquid. The formula for calculating the leaching rate of vanadium and $\mathrm{Si}$ is as follows:

$$
\eta=\frac{m_{1}}{m_{2}} \times 100 \%
$$

where $\eta$ represents the leaching rate of vanadium and $S i, m_{1}$ is the content of vanadium and $\mathrm{Si}$ in the leaching solution, and $m_{2}$ is the quality of vanadium and $\mathrm{Si}$ in roasted clinker.

\subsection{Calcification and Precipitation of Vanadium}

Take a certain amount of vanadium leaching solution in a flask with three necks, add a certain amount of $\mathrm{CaO}$ (the molar ratio of $\mathrm{N}_{\mathrm{Ca}} / \mathrm{N}_{\mathrm{V}}$ is 0.45 to 0.7 ), and 2 times the molar amount of hydrochloric acid at a certain temperature $\left(60-99{ }^{\circ} \mathrm{C}\right)$ in a water bath for a certain time (45 $\mathrm{min} \sim 95 \mathrm{~min})$. In the process of reaction, the $\mathrm{pH}$ of the solution is kept at $6.7 \pm 0.1$ with the appropriate amount of hydrochloric acid. After the reaction, the filtrate and solid phase were obtained by vacuum pumping, and the content of vanadium in the filtrate was analyzed. Figure 1 is a schematic diagram of the whole process of vanadium slag roasting-leaching-calcification and vanadium precipitation. 


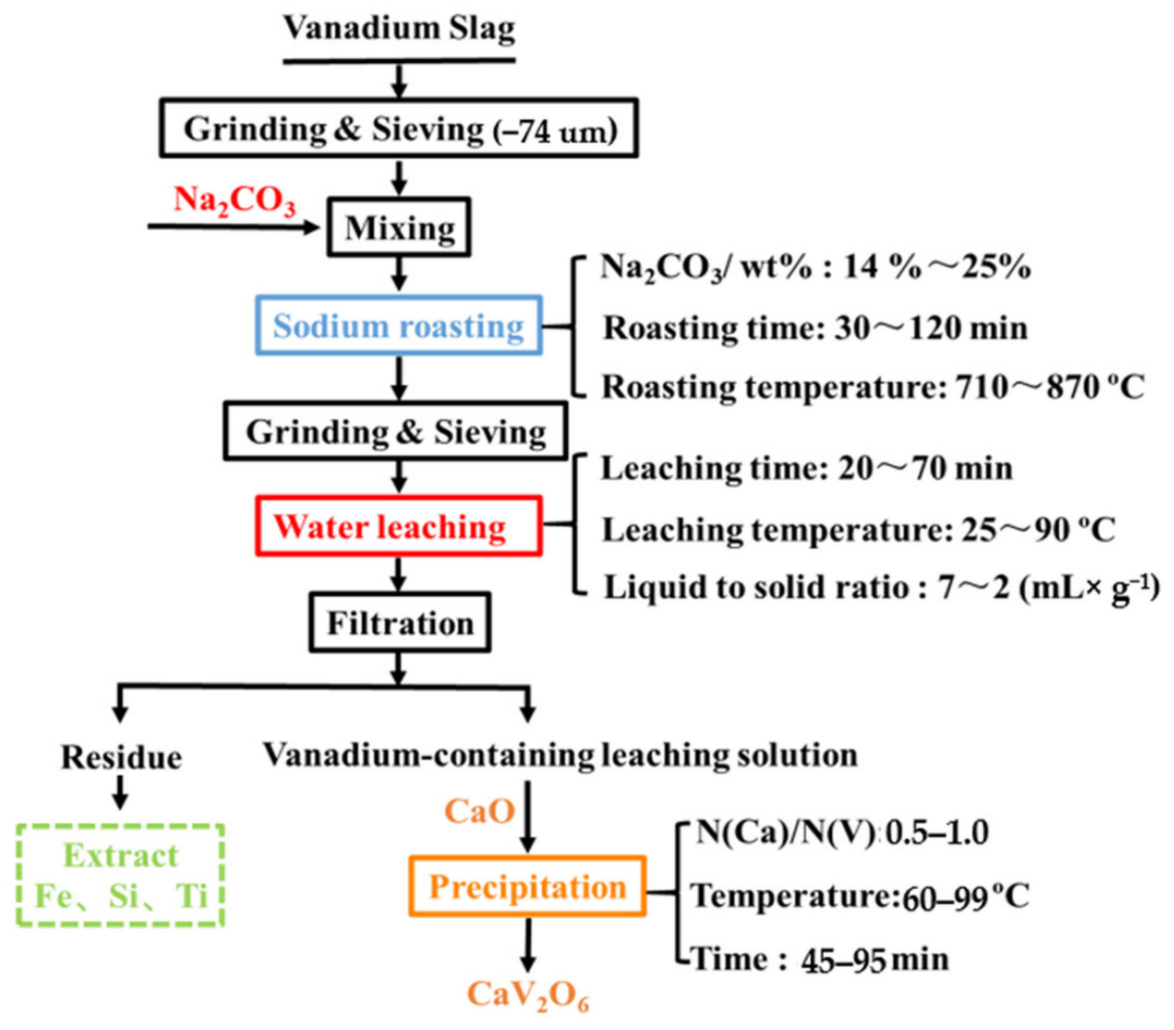

Figure 1. Flow chart of the whole process.

The formula for calculating the precipitation rate of vanadium is:

$$
\xi=1-\frac{m_{1}}{m_{2}} \times 100 \%
$$

where $\xi$ represents the vanadium precipitation rate, $m_{2}$ is the quantity of vanadium in the vanadium purification solution, and $m_{1}$ is the quantity characterization of vanadium in the supernatant of vanadium precipitation.

\subsection{Characterization}

The content of various elements in the leaching solution and the content of vanadium in the vanadium precipitation wastewater was analyzed by inductively coupled plasma atomic emission spectrometry (ICP-AES, Optima 5300D, Perkin-Elmer Instruments Co., Ltd., New York, NY, USA). The chemical components of vanadium slag and vanadium precipitated products were analyzed by X-ray fluorescence spectroscopy. An X-ray diffractometer (XRD, Panak Amsterdam, The Netherlands) using $\mathrm{Cu}-\mathrm{K} \alpha$ rays $(\lambda=1.5406 \AA$ ), voltage: $40 \mathrm{kV}$, current: $30 \mathrm{~mA}$, scan rate: $5^{\circ} / \mathrm{min}$, scan range: $2 \theta=10-80^{\circ}$ was used to analyze the phase of vanadium slag, roasting slag, and leaching residue as well as vanadium precipitation products. A field emission scanning electron microscope (SEM-EDS, EDAX, Portland, USA) and its energy spectrum analysis are used to analyze the surface morphology of vanadium slag, roasting slag, and leaching residue. And element distribution, X-ray photoelectron spectroscopy (XPS) was used to characterize the valence states of major elements in vanadium slag, roasting slag, and residue.

\section{Results and Discussion}

\subsection{Effect of Conditions of Roasting with Sodium on The Leaching Rate of Vanadium and Silicon}

Figure 2 shows the effects of $\mathrm{Na}_{2} \mathrm{CO}_{3}$ addition, roasting temperature, and roasting time on the leaching rate of $\mathrm{V}$ and $\mathrm{Si}$. The roasted sample is leached with water at $90{ }^{\circ} \mathrm{C}$ for $60 \mathrm{~min}$, the ratio of liquid to solid is 5 to 1, and the stirring speed is $300 \mathrm{rpm}$. In Figure 2a, 
the vanadium leaching rate increases at first and then decreases with the increase of $\mathrm{Na}_{2} \mathrm{CO}_{3}$ content. When the mass fraction of $\mathrm{Na}_{2} \mathrm{CO}_{3}$ is $20 \%$, the maximum leaching rate of vanadium is $89.54 \%$, which is due to the formation of soluble sodium salts such as $\mathrm{NaVO}_{3}$, $\mathrm{Na}_{3} \mathrm{VO}_{4}$ and $\mathrm{Na}_{4} \mathrm{~V}_{2} \mathrm{O}_{7}$. When the amount of sodium carbonate is more than $20 \%$, the leaching rate of vanadium decreases, mainly because too much $\mathrm{Na}_{2} \mathrm{CO}_{3}$ is easy to form a substance $\left(\mathrm{NaFeSi}_{2} \mathrm{O}_{6}\right)$ with a low melting point with vanadium slag, which leads to melting and sintering of the sample, wrapping on the surface of roasting slag and reducing the leaching of vanadium. For the leaching behavior of $\mathrm{Si}$, the results show that the leaching rate of $\mathrm{Si}$ increases gradually with the increase of $\mathrm{Na}_{2} \mathrm{SiO}_{3}$ content, this is because part of excess $\mathrm{Na}_{2} \mathrm{CO}_{3}$ is easy to combine with $\mathrm{SiO}_{2}$ in vanadium slag to form $\mathrm{Na}_{2} \mathrm{SiO}_{3}$, When the leaching solution is alkaline, $\mathrm{Na}_{2} \mathrm{SiO}_{3}$ is retained in the leaching solution, so that the leaching rate of $\mathrm{Si}$ in the leaching solution gradually increases. When the leaching rate of vanadium reaches the highest, the leaching rate of $\mathrm{Si}$ is $1.96 \%$.
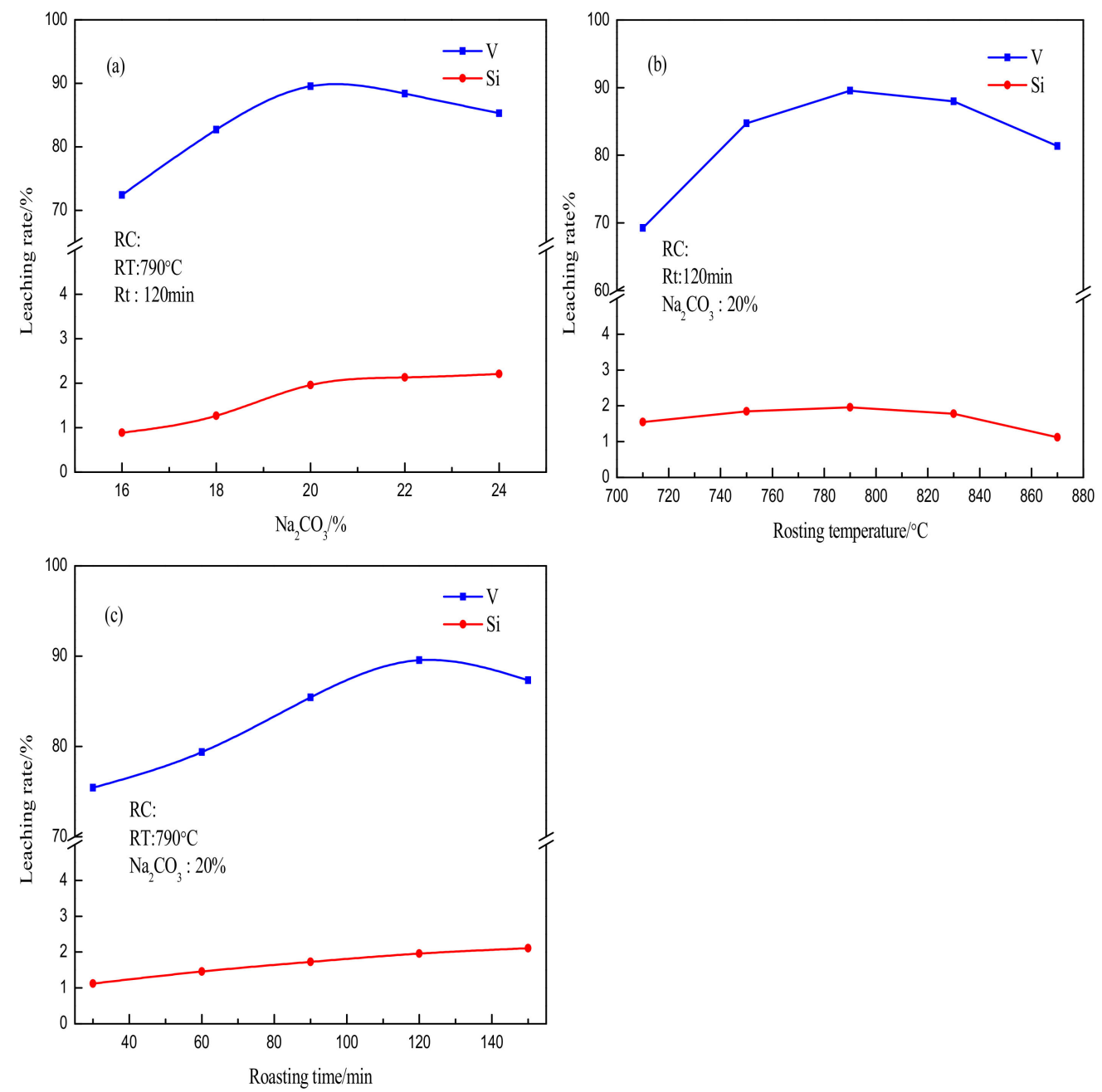

Figure 2. Effects of $\mathrm{Na}_{2} \mathrm{CO}_{3}$ addition (a), roasting temperature (b), and roasting time (c) on leaching rate of vanadium and silicon.

In Figure 2b, when the roasting temperature of vanadium slag is $710{ }^{\circ} \mathrm{C}, 69.25 \%$ of $\mathrm{V}$ is leached. It can be inferred that most of the vanadium in the vanadium slag has undergone sodiumization and oxidation at $710{ }^{\circ} \mathrm{C}$, forming soluble sodium vanadate. When the temperature rises to $790{ }^{\circ} \mathrm{C}$, the highest vanadium leaching rate is $89.54 \%$. When the temperature exceeds $790{ }^{\circ} \mathrm{C}$, the vanadium leaching rate decreases gradually, This is since the high roasting temperature leads to the appearance of the glass phase in the roasted sample, which makes the material denser and reduces the vanadium leaching. However, 
the leaching rate of $\mathrm{Si}$ is opposite to that of $\mathrm{V}$, which is attributed to the insoluble $\mathrm{NaFeSi}_{2} \mathrm{O}_{6}$ and $\mathrm{NaTiSi}_{2} \mathrm{O}_{6}$ in the phase of vanadium slag when the roasting temperature is higher than $710^{\circ} \mathrm{C}$, which reduces the leaching rate of Si. The leaching rate of silicon is $1.96 \%$ at $790^{\circ} \mathrm{C}$.

The effect of roasting time on the leaching rate of $\mathrm{V}$ and $\mathrm{Si}$ is shown in Figure 2c. With the extension of roasting time, the leaching rate of vanadium increases gradually, mainly because the trivalent vanadium in vanadium slag is fully oxidized and natrified with the extension of roasting time. When the roasting time exceeds $120 \mathrm{~min}$, the leaching rate of vanadium decreases, which is mainly due to the long residence time of vanadium slag in the high-temperature zone and the caking of vanadium slag samples. It is not conducive to the oxidation and natrification of low-valent vanadium. At the same time, with the extension of roasting time, the leaching rate of $\mathrm{Si}$ increased slightly, and when the roasting time was $120 \mathrm{~min}$, the leaching rates of vanadium and $\mathrm{Si}$ were $89.54 \%$ and $1.96 \%$, respectively. Through the single factor roasting experiment, the optimum roasting conditions are determined as follows: the roasting temperature is $790{ }^{\circ} \mathrm{C}$, the roasting time is $120 \mathrm{~min}$ and the amount of $\mathrm{Na}_{2} \mathrm{CO}_{3}$ is $20 \%$.

\subsection{Effect of Leaching Conditions on The Leaching Rate of Vanadium and Silicon}

Figure 3 shows the effects of leaching liquid-solid ratio, leaching time, and leaching temperature on the leaching rate of $\mathrm{V}$ and $\mathrm{Si}$. The roasting sample was obtained under the conditions of $20 \% \mathrm{Na}_{2} \mathrm{CO}_{3}$ addition, roasting temperature $790{ }^{\circ} \mathrm{C}$, roasting time $120 \mathrm{~min}$, and leaching solution stirring speed $300 \mathrm{r} / \mathrm{min}$. In Figure $3 \mathrm{a}$, the leaching rate of vanadium increases gradually with the increase of the liquid-solid ratio, and the maximum vanadium leaching rate reaches $89.54 \%$ when the liquid-solid ratio is 5 to 1 . This is mainly because the viscosity of the leaching solution decreases gradually with the increase of liquidsolid ratio, and the diffusion resistance of soluble sodium vanadate into the solution decreases gradually, which makes the soluble sodium vanadate can be leached more easily. Meanwhile, with the increase of solid-liquid ratio, the alkalinity of vanadium leaching solution also decreases, which is harmful to the leaching of vanadium (sodium vanadate is the salt of strong alkali weak acid, the vanadate ion is easily hydrolyzed, making the solution alkaline. The higher the alkalinity, the more it can inhibit the hydrolysis of vanadate ion, which is beneficial to the leaching of vanadium.), This explains why the leaching rate of vanadium will decrease when the liquid-to-solid ratio is greater than 5:1 When the leaching rate of vanadium reaches the maximum, the leaching rate of $\mathrm{Si}$ is $1.96 \%$.

Figure $3 \mathrm{~b}$ shows the effect of leaching time on the leaching rate of $\mathrm{V}$ and $\mathrm{Si}$. With the increase of leaching time, the leaching rate increases gradually. When the leaching time is $60 \mathrm{~min}$, the leaching rate of vanadium reaches $89.54 \%$. This is due to the physical dissolution of soluble sodium vanadate in the roasted sample and increasing the leaching time can effectively increase the leaching rate. When the leaching time exceeds $60 \mathrm{~min}$, the leaching rate of vanadium increases slightly. Therefore, the suitable leaching time is $60 \mathrm{~min}$. The leaching rate of $\mathrm{Si}$ is the same as that of vanadium. When the leaching time is $70 \mathrm{~min}$, the maximum leaching rate of $\mathrm{Si}$ is $2.18 \%$.

Figure $3 \mathrm{c}$ shows the effect of leaching temperature on the leaching rate of $\mathrm{V}$ and $\mathrm{Si}$. With the increase of leaching temperature, the leaching rate of vanadium increases gradually. When the Leaching temperature is $50{ }^{\circ} \mathrm{C}$, the leaching rate of vanadium is only $62.45 \%$. When the temperature rises to $90{ }^{\circ} \mathrm{C}$, the leaching rate of vanadium is $89.54 \%$. This is mainly since increasing temperature can improve the solubility of soluble sodium vanadate, on the other hand, the increasing temperature can improve the movement ability of water molecules, reduce the viscosity of the solution and gradually increase the leaching rate of vanadium. When the temperature of the leaching solution rises to $99^{\circ} \mathrm{C}$, the leaching rate of vanadium is $90.13 \%$, which indicates that when the leaching temperature is higher than $90^{\circ} \mathrm{C}$, the contribution of temperature to the leaching rate of vanadium becomes very small. The leaching trend of $\mathrm{Si}$ is consistent with that of vanadium. Increasing temperature will increase the leaching rate of $\mathrm{Si}$. When the temperature is $99^{\circ} \mathrm{C}$, the maximum leaching 
rate of $\mathrm{Si}$ is $2.01 \%$. Through the single factor leaching method, the optimum leaching conditions can be determined as follows: the ratio of liquid to solid is 5 to 1 , the leaching time is $60 \mathrm{~min}$ and the leaching temperature is $90^{\circ} \mathrm{C}$.
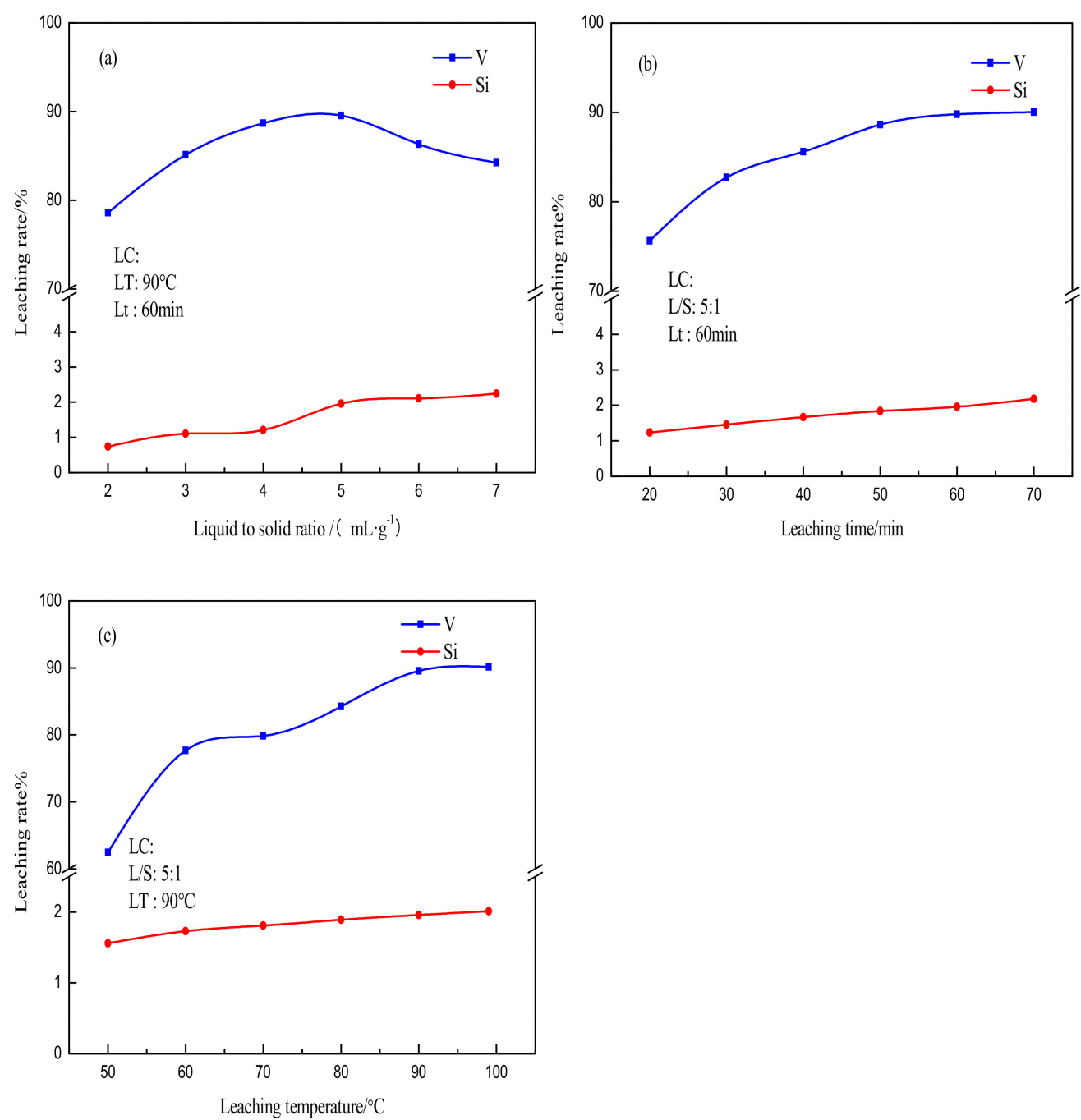

Figure 3. Effects of leaching liquid-solid ratio (a), leaching time (b), and leaching temperature (c) on vanadium leaching rate.

Besides, the concentration of the main ions in the vanadium leaching solution under the optimal conditions is shown in Table 2. The results show that the concentration of impurities is far less than that of vanadium ion, which indicates that the vanadium-containing leaching solution can be directly used as a vanadium source without purification.

Table 2. Concentration of main ions in vanadium leaching solution.

\begin{tabular}{ccccccccc}
\hline Ion Species & $\mathbf{V}$ & $\mathbf{N a}$ & $\mathbf{S i}$ & $\mathbf{P}$ & $\mathbf{C r}$ & $\mathbf{T i}$ & $\mathbf{M n}$ & $\mathbf{F e}$ \\
\hline Concentration (g/L) & 8.23 & 12.8 & 0.251 & 0.018 & 0.0013 & 0.0021 & 0.001 & 0.012 \\
Concentration ratio of V/impurity elements & 1 & 0.642 & 32.78 & 457.22 & 6330.77 & 3919.05 & 8230 & 685.83 \\
\hline
\end{tabular}

Figures 4 and 5 show the phase, surface morphology, and element distribution of vanadium slag, roasting slag, and residue. It can be seen from Figure 4 that vanadium slag is mainly composed of vanadium iron spinel phase $\left(\mathrm{FeV}_{2} \mathrm{O}_{4}\right)$, silicate phase $\left(\mathrm{Fe}_{2} \mathrm{SiO}_{4}\right)$, and titanium spinel phase $\left(\mathrm{Fe}_{2.5} \mathrm{Ti}_{0.5} \mathrm{O}_{4}\right)$. Combined with Figure 5a, it can be seen that most 
of the surface distribution of vanadium and titanium elements coincide with each other, mainly because the chemical properties of titanium and vanadium are similar and often associated. It can be seen from Figure 4 that the spinel and silicate phases in vanadium slag have been decomposed after roasting, which can be observed from the disappearance of the peaks of these phases in the roasting slag, and replaced by new phases such as $\mathrm{Fe}_{2} \mathrm{O}_{3}, \mathrm{Na}_{2} \mathrm{SiO}_{3}, \mathrm{Na}_{4} \mathrm{~V}_{2} \mathrm{O}_{7}$, and $\mathrm{NaVO}_{3}$, the main reactions of sodium vanadate formation in Equations (3) and (4).The distribution of vanadium and sodium in Figure $5 \mathrm{~b}$ is almost the same, which proves the existence of sodium vanadate and the repeated distribution of $\mathrm{Na}$, $\mathrm{Fe}$, and $\mathrm{Si}$, which proves the existence of $\mathrm{NaFeSi}_{2} \mathrm{O}_{6}$. This corresponds to the diffraction peak of $\mathrm{NaFeSi}_{2} \mathrm{O}_{6}$ in Figure 4. After the roasting slag was leached by water, the soluble $\mathrm{Na}_{4} \mathrm{~V}_{2} \mathrm{O}_{7}, \mathrm{NaVO}_{3}$, and $\mathrm{NaSiO}_{3}$ phases disappeared and transferred into the vanadium leaching solution, and the insoluble $\mathrm{Fe}_{2} \mathrm{O}_{3}, \mathrm{NaFeSi}_{2} \mathrm{O}_{6}$, and $\mathrm{NaTiSi}_{2} \mathrm{O}_{6}$ remained in the residue. At the same time, combined with Figure $5 c$, it is known that the $\mathrm{V}$ in the residue is uniformly distributed and the content is greatly reduced, which is different from the segregation behavior in the roasting slag, which is a typical manifestation of vanadium water leaching. At the same time, the surface distributions of $\mathrm{Fe}, \mathrm{Si}$, and $\mathrm{Na}$ are also highly overlapping, which shows that silicon is retained in the residue mainly in the form of $\mathrm{NaFeSi}_{2} \mathrm{O}_{6}$ :

$$
\begin{aligned}
& \mathrm{FeV}_{2} \mathrm{O}_{4}+\mathrm{Na}_{2} \mathrm{CO}_{3}+1.25 \mathrm{O}_{2}=2 \mathrm{NaVO}_{3}+1 / 2 \mathrm{Fe}_{2} \mathrm{O}_{3}+\mathrm{CO}_{2} \\
& 2 \mathrm{FeV}_{2} \mathrm{O}_{4}+4 \mathrm{Na}_{2} \mathrm{CO}_{3}+2.5 \mathrm{O}_{2}=2 \mathrm{Na}_{4} \mathrm{~V}_{2} \mathrm{O}_{7}+\mathrm{Fe}_{2} \mathrm{O}_{3}+4 \mathrm{CO}_{2}
\end{aligned}
$$

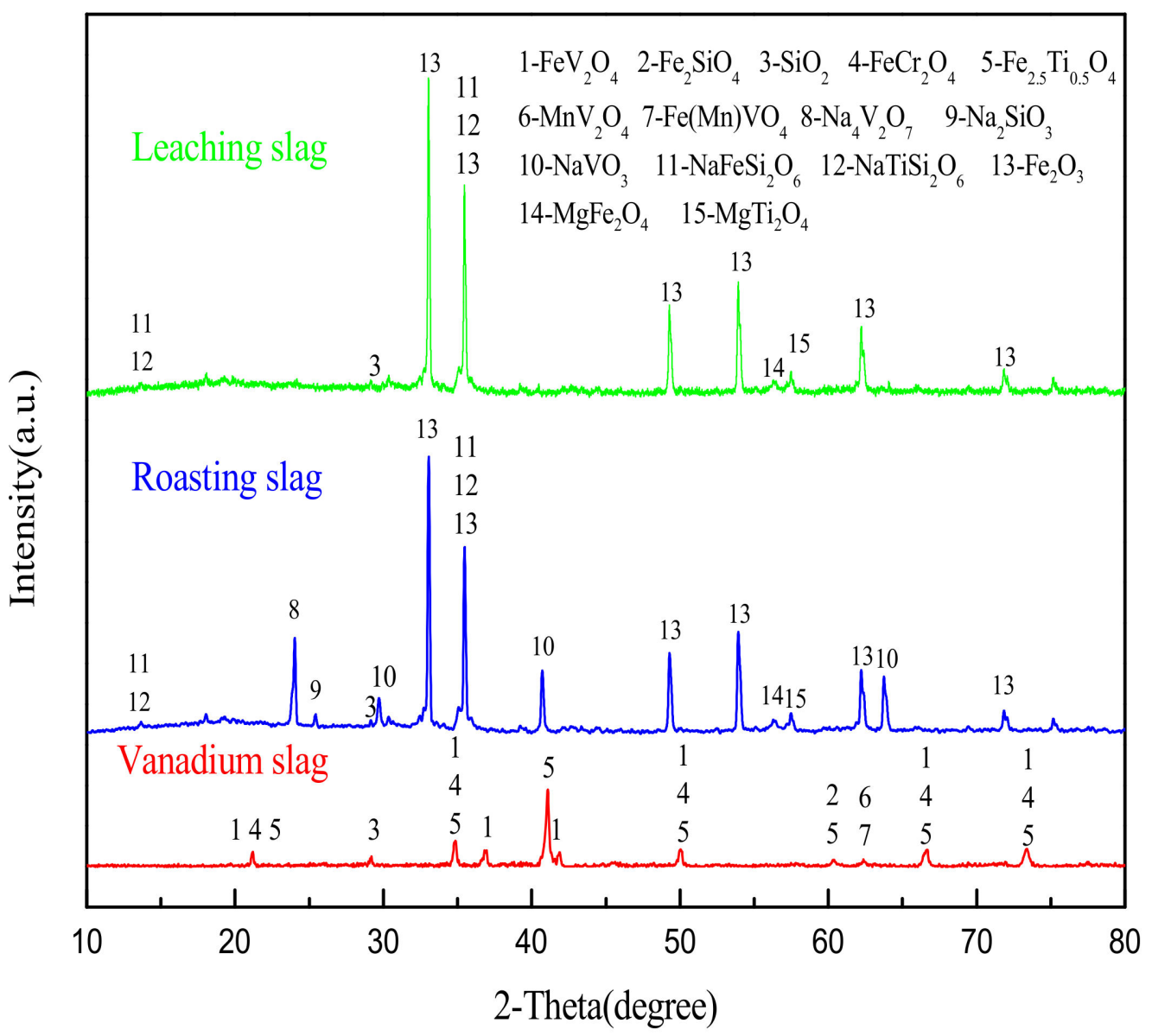

Figure 4. XRD patterns of Vanadium slag and the samples after roasting and leaching. 

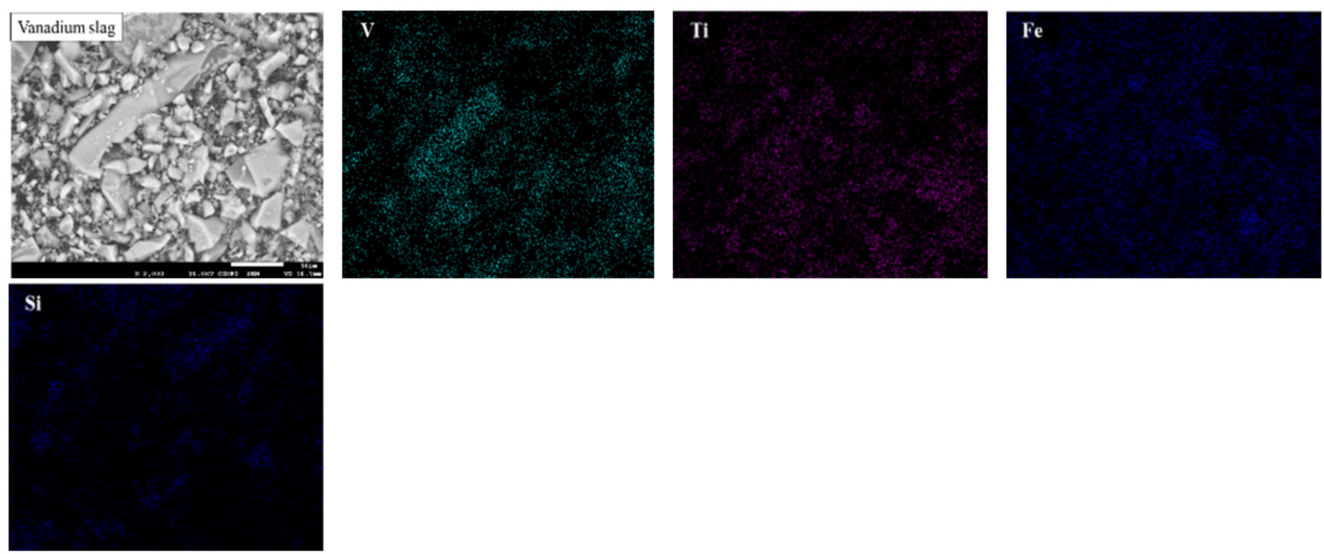

(a) Areal distribution of different elements in vanadium slag
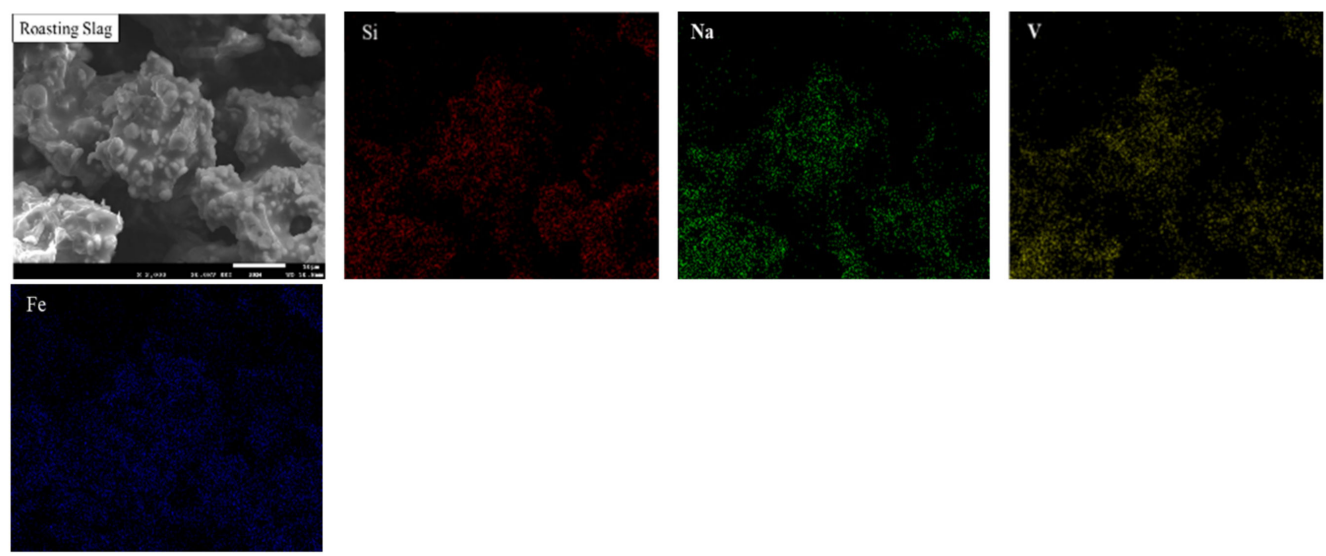

(b) Areal distribution of different elements in roasting slag
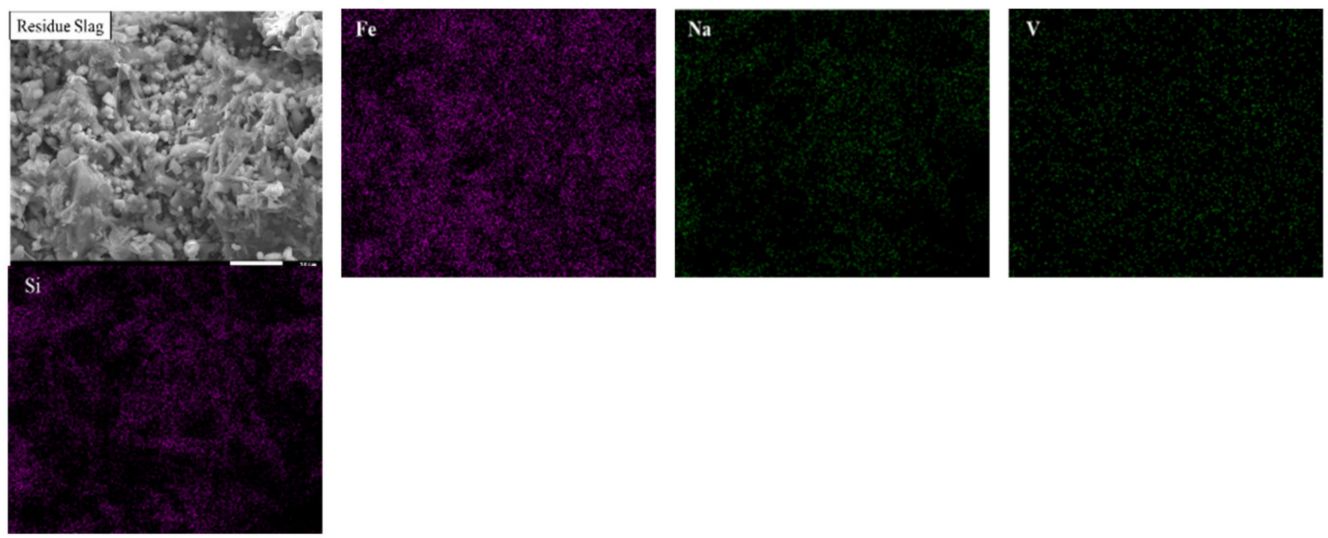

(c) Areal distribution of different elements in residue slag

Figure 5. Microstructure and elements distribution of vanadium slag and during roasting and leaching.

Figure 6 shows the X-ray photoelectron spectroscopy of vanadium slag, roasted slag, and residue samples (a) global XPS; (b) the valence change of V; and the valence change of Fe. It can be seen from Figure 6 that vanadium slag mainly contains $\mathrm{Fe}, \mathrm{Mn}, \mathrm{V}, \mathrm{Si}, \mathrm{O}, \mathrm{Ca}$, and $\mathrm{C}$ elements; roasting slag mainly contains $\mathrm{C}, \mathrm{Na}, \mathrm{O}, \mathrm{V}, \mathrm{Ca}, \mathrm{C}$ and $\mathrm{Si}$, but Fe element peak is very small, this is because XPS is a surface analysis technique, the formed sodium 
vanadate covers the surface of vanadium slag, resulting in the annihilation of Fe peak; the residue mainly contains $\mathrm{C}, \mathrm{Na}, \mathrm{O}, \mathrm{Fe}, \mathrm{V}, \mathrm{Ti}, \mathrm{Ca}$ and $\mathrm{Si}$.

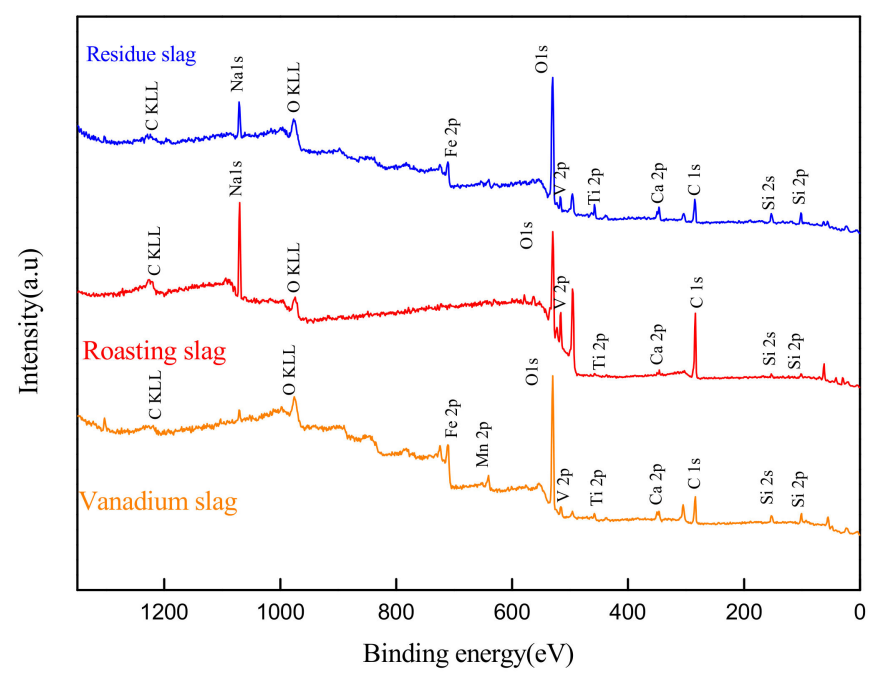

(a) XPS analysis of vanadium slag, roasting slag and residue
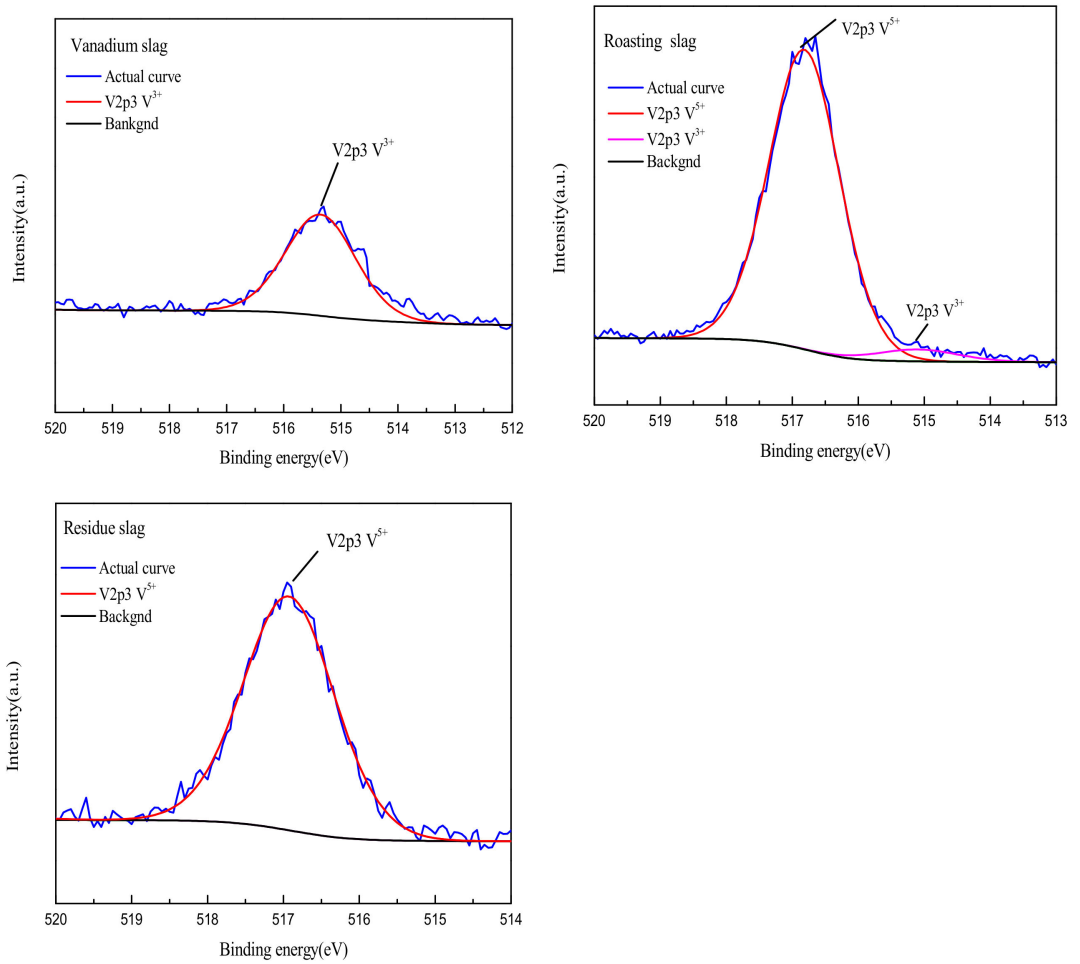

(b) High resolution spectrum characterization of different elements in vanadium slag

Figure 6. Cont. 

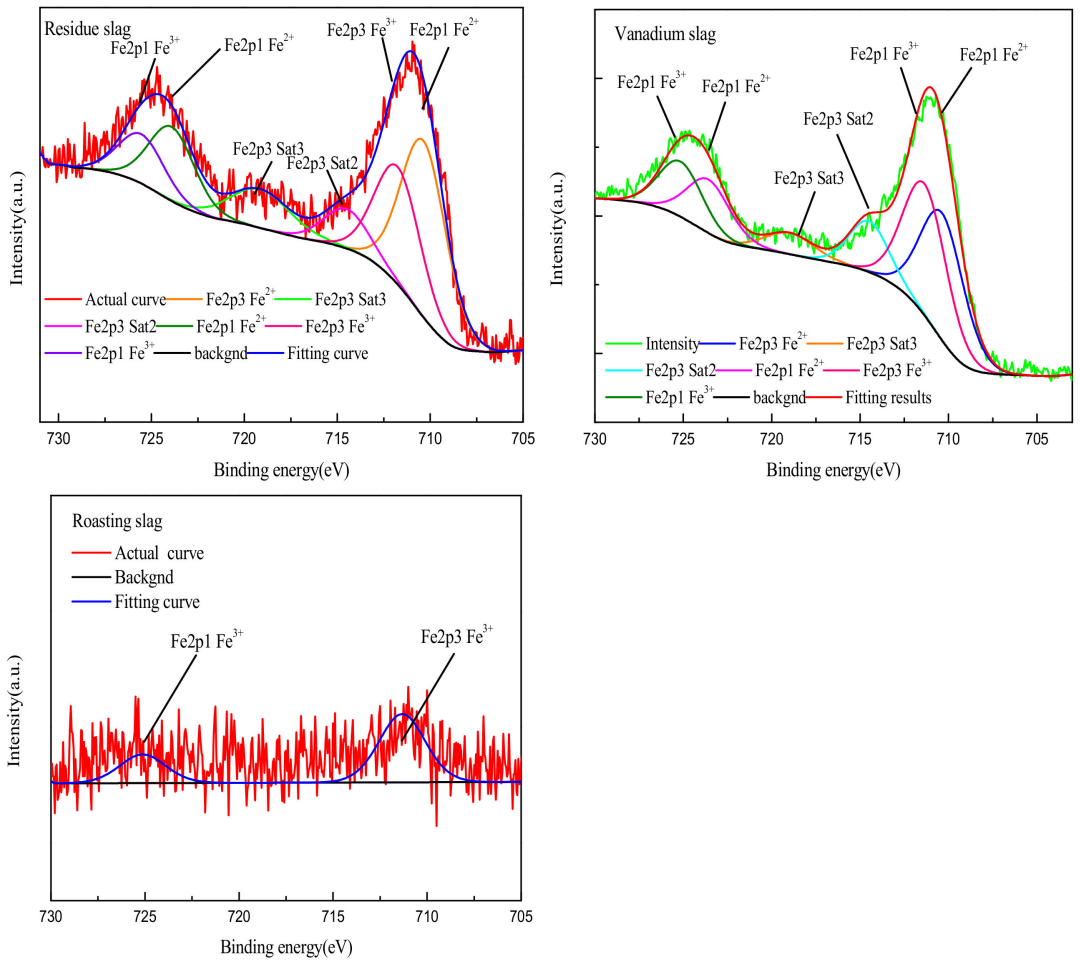

(c) High resolution spectrum characterization of different elements in roasting slag
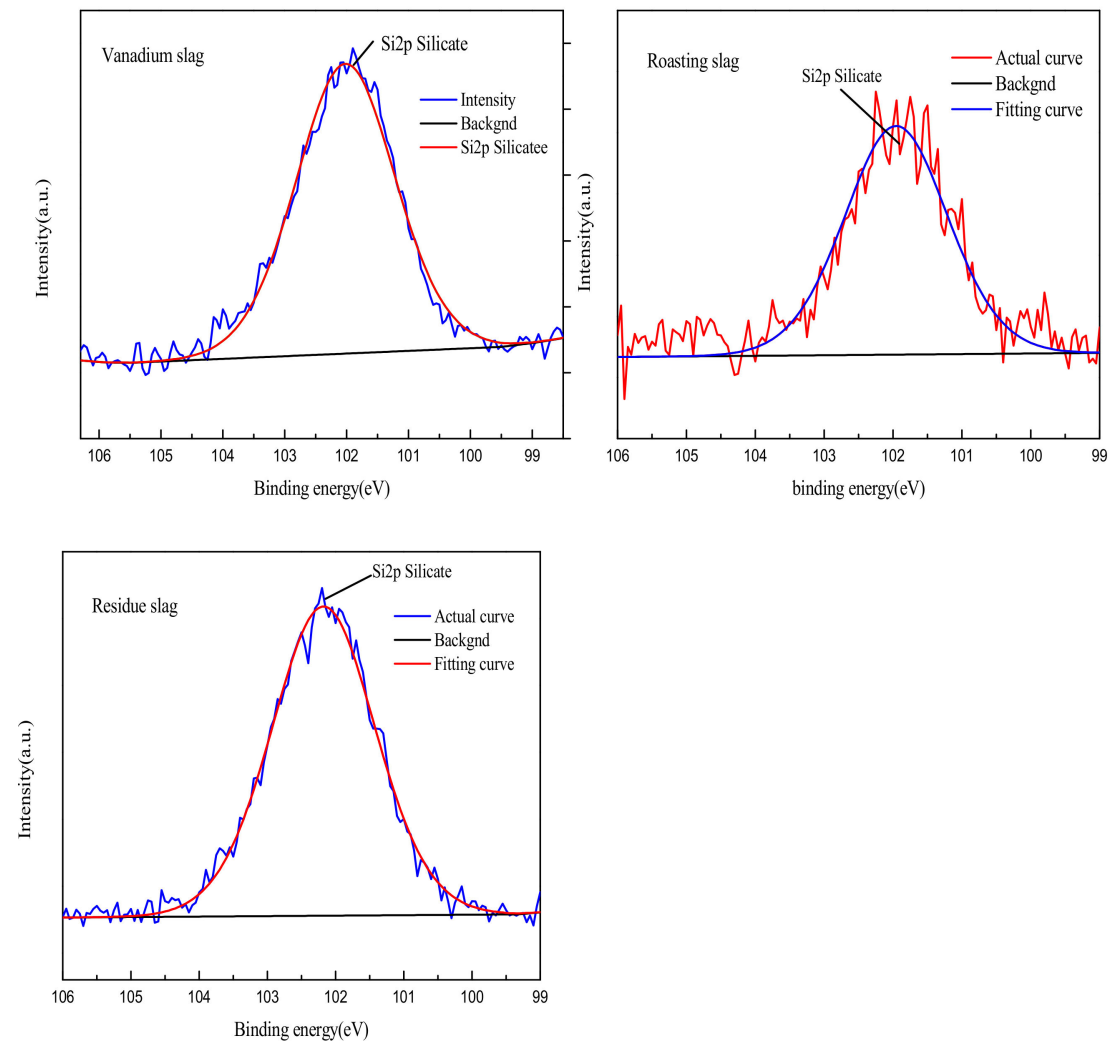

(d) High resolution spectrum characterization of different elements in residue slag

Figure 6. XPS analysis of vanadium slag, roasting slag and residue (a) Global XPS; (b) valence states change of V; (c) valence states change of Fe. 
The vanadium on the surface of vanadium slag mainly exists in the form of trivalent vanadium, and the binding energy of trivalent vanadium is $515.5 \mathrm{eV}$, which is consistent with the reference [17] this is the characteristic valence state of vanadium in Spinel of vanadium slag. The Fe element is in the state of coexistence of trivalent iron and bivalent $\mathrm{Fe}$, in which the proportion of bivalent $\mathrm{Fe}^{2+}$ is $52.89 \%$. The proportion of $\mathrm{Fe}^{3+}$ is $47.11 \%$, such as bivalent Fe2 $\mathrm{p}_{3 / 2}$ near $710 \mathrm{eV}$ and trivalent Fe2 $\mathrm{p}_{3 / 2}$, near $711 \mathrm{ev}$, bivalent Fe2 $\mathrm{p}_{1 / 2}$ near $723 \mathrm{eV}$ and trivalent Fe2 $\mathrm{p}_{1 / 2}$, near $725 \mathrm{eV}$, which corresponds to $\mathrm{Fe}_{2} \mathrm{SiO}_{4}$ and $\mathrm{FeV}_{2} \mathrm{O}_{4}$ in vanadium slag. It can be seen from Figure 6 , When the vanadium slag is roasted by sodiumization, the valence state of vanadium is mainly 5, and the binding energy of the $\mathrm{V}$ element in the roasted slag increases from about $515.5 \mathrm{eV}$ to near $517 \mathrm{eV}$, which is due to the oxidation of spinel. Among them, the proportion of $\mathrm{V}^{5+}$ is $95.6 \%$ and the proportion of $\mathrm{V}^{3+}$ is $4.4 \%$, which shows that vanadium has been transformed from trivalent vanadium to pentavalent vanadium after roasting at $790{ }^{\circ} \mathrm{C}$ for $120 \mathrm{~min}$, which achieves the purpose of sodium roasting. The Fe element mainly exists in the form of $\mathrm{Fe}^{3+}$, which indicates that $\mathrm{Fe}^{2+}$ has been oxidized to $\mathrm{Fe}^{3+}$. It is worth noting that the $\mathrm{Fe}$ and high-resolution peaks are so weak that they cannot be shown on the full spectrum peak. This is because the sodium vanadate formed during roasting is mostly distributed on the surface of the roasting slag, and the formation of sodium vanadate benefits from the decomposition of vanadate spinel. Under this condition, the material interdependent with sodium vanadate must be the $\mathrm{Fe}^{3+}$ ion after oxidation. Therefore, the roasting slag can only detect $\mathrm{Fe}^{3+}$ with low peak strength during XPS scanning but cannot detect oxidized $\mathrm{Fe}^{2+}$.

The high-resolution characterization of different elements in the leaching residue shows that the $\mathrm{V}$ element mainly exists in the form of pentavalent vanadate, which indicates that some vanadates of pentavalent $\mathrm{V}$ ions are not leached, and the distribution of Fe elements shows the coexistence of bivalent Fe and trivalent Fe, which is because the naked leakage of internal unoxidized $\mathrm{Fe}^{2+}$ was detected by XPS after the leaching of roasting slag.

For silicon element, its XPS analysis shows that the binding energy of silicon element in three kinds of slag is all near $102 \mathrm{eV}$ in Figure 6, indicating that Si element mainly shows the chemical state of silicate, which is consistent with the corresponding XRD diagram. Silicon exists in the form of $\mathrm{Fe}_{2} \mathrm{SiO}_{4}$ in vanadium slag and in roasting slag and residue in the form of $\mathrm{NaFeSi}_{2} \mathrm{O}_{6}$ and $\mathrm{NaTiSi}_{2} \mathrm{O}_{6}$.

\subsection{Thermodynamic Simulation}

The thermodynamic simulation is carried out by Factsage software (Montreal, Canada and, Achen, Germany). According to the composition and phase of vanadium slag, vanadium in vanadium slag mainly exists in the form of $\mathrm{FeV}_{2} \mathrm{O}_{4}$ and silicon mainly in the form of $\mathrm{Fe}_{2} \mathrm{SiO}_{4}$. According to the calculation of Table 1, in the balance module of Factsage software, the relative amount of initial $\mathrm{FeV}_{2} \mathrm{O}_{4}$ is simplified to be $0.5 \mathrm{~mol}$ and the relative amount of $\mathrm{Fe}_{2} \mathrm{SiO}_{4}$ is $1.5 \mathrm{~mol}$. The effects of the amount of oxygen and sodium carbonate on the phase transformation of $\mathrm{Si}$ and $\mathrm{V}$ elements in vanadium slag were simulated.

As shown in Figure $7 \mathrm{a}$, when the initial $\mathrm{Fe}_{2} \mathrm{SiO}_{4}$ and $\mathrm{FeV}_{2} \mathrm{O}_{4}$ with an initial content of $1.5 \mathrm{~mol}$ and $0.5 \mathrm{~mol}$ were oxidized at $790{ }^{\circ} \mathrm{C}, 0.538 \mathrm{~mol}$ of $\mathrm{Fe}_{2} \mathrm{SiO}_{4}$ was decomposed into $1.076 \mathrm{~mol}$ of $\mathrm{FeO}$ and $0.538 \mathrm{~mol}$ of $\mathrm{SiO}_{2}$. After that, the oxidation reaction began, $0.962 \mathrm{~mol}$ of $\mathrm{Fe}_{2} \mathrm{SiO}_{4}$ was oxidized into $\mathrm{Fe}_{2} \mathrm{O}_{3}, \mathrm{Fe}_{3} \mathrm{O}_{4}$, and $\mathrm{SiO}_{2}$. With the formation of $\mathrm{Fe}_{2} \mathrm{O}_{3} \mathrm{FeO}$ and oxidation and $\mathrm{Fe}_{3} \mathrm{O}_{4}$, which is given priority to with oxidation for $\mathrm{Fe}_{3} \mathrm{O}_{4}$, this suggests that the affinity of Fe and $\mathrm{O} 8 / 3$ valence than the valence of 3 Fe affinity, and $\mathrm{FeV}_{2} \mathrm{O} 4$ oxidation decomposition, until the $\mathrm{O}_{2}$ consumption came to 0.42 mol, $\mathrm{FeV}_{2} \mathrm{O}_{4}$ oxidative decomposition of the beginning of the formation of $\mathrm{Fe}\left(\mathrm{VO}_{3}\right)_{2}$ and $\mathrm{V}_{2} \mathrm{O}_{5}$, and after that with the increase of oxygen consumption, $\mathrm{SiO}_{2}$ content remains the same, gradually transforms the $\mathrm{Fe}_{3} \mathrm{O}_{4} \mathrm{Fe}_{2} \mathrm{O}_{3}$, As a result, the Content of $\mathrm{Fe}_{2} \mathrm{O}_{3}$ gradually increases. When the oxygen consumption is $1.4 \mathrm{~mol}$, the content of each phase remains constant. At this time, $\mathrm{V}_{2} \mathrm{O}_{5}$ is $0.2 \mathrm{~mol}, \mathrm{Fe}\left(\mathrm{VO}_{3}\right)_{2}$ is $0.3 \mathrm{~mol}, \mathrm{SiO}_{2}$ is $1.5 \mathrm{~mol}$, and $\mathrm{Fe}_{2} \mathrm{O}_{3}$ is $1.6 \mathrm{~mol}$. 


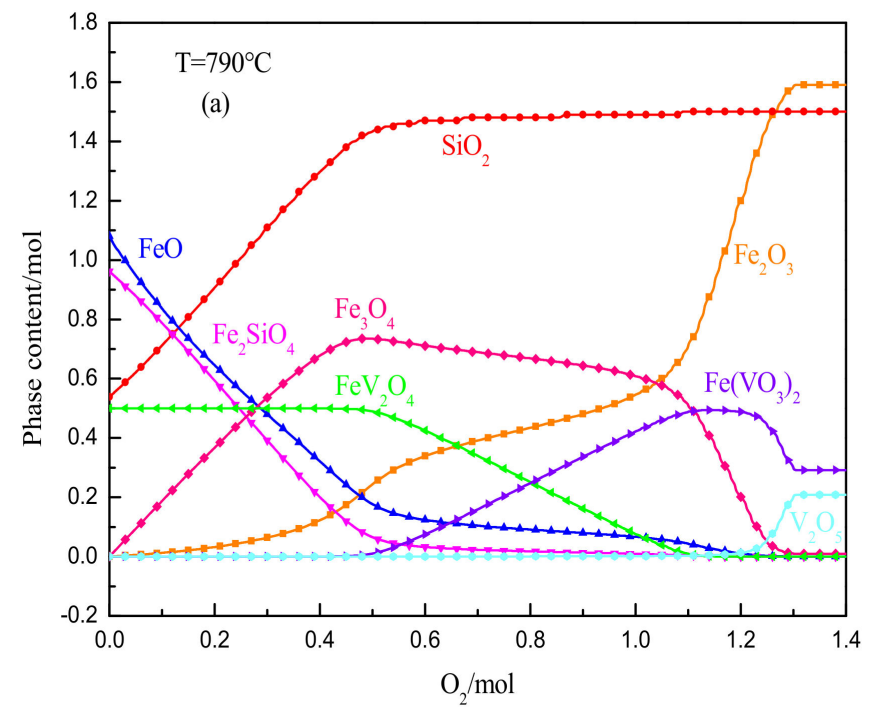

(a) Oxidation phase transition of spinel and silicate

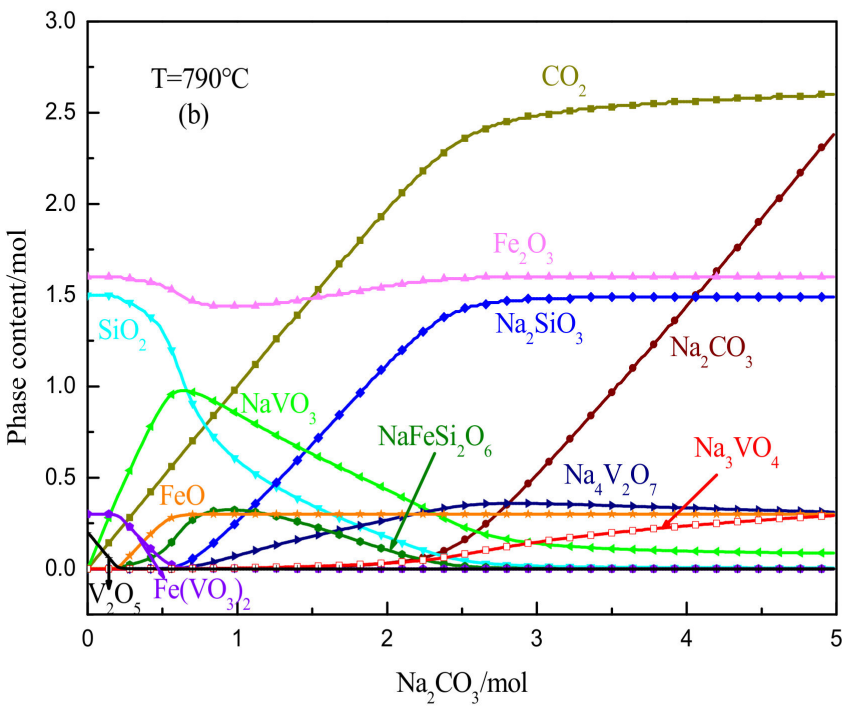

(b) Phase transformation process of vanadium slag sodium reaction

Figure 7. Phase transformation of vanadium slag during sodium roasting.

It can be seen from Figure $7 \mathrm{~b}$ that $\mathrm{V}_{2} \mathrm{O}_{5}$ first consumes $0.2 \mathrm{~mol}$ of $\mathrm{Na}_{2} \mathrm{CO}_{3}$ to form $\mathrm{NaVO}_{3}$, while $\mathrm{Fe}_{2} \mathrm{O}_{3}$ and $\mathrm{SiO}_{2}$, which are reaction pairs of reaction substances, also react with $\mathrm{Na}_{2} \mathrm{CO}_{3}$ to form $\mathrm{NaFeSi}_{2} \mathrm{O}_{6}$. When $\mathrm{Na}_{2} \mathrm{CO}_{3}$ consumption exceeded $0.2 \mathrm{~mol}, \mathrm{Fe}\left(\mathrm{VO}_{3}\right)_{2}$ also began to participate in the reaction with $\mathrm{Na}_{2} \mathrm{CO}_{3}$ to form $\mathrm{NaVO}_{3}$ and $\mathrm{FeO}$. When $\mathrm{Na}_{2} \mathrm{CO}_{3}$ consumption was $0.5 \mathrm{~mol}$, all $\mathrm{V}$ in $\mathrm{V}_{2} \mathrm{O}_{5}$ and $\mathrm{Fe}\left(\mathrm{VO}_{3}\right)_{2}$ were transferred to $\mathrm{V}$ of $\mathrm{NaVO}_{3}$, and the environment of $\mathrm{V}$ atoms was changed. Later, with the continuous increase of consumption of $\mathrm{Na}_{2} \mathrm{CO}_{3}, \mathrm{NaVO}_{3}$ combined with $\mathrm{Na}_{2} \mathrm{CO}_{3}$ to form $\mathrm{Na}_{3} \mathrm{VO}_{4}$ and $\mathrm{Na}_{4} \mathrm{~V}_{2} \mathrm{O}_{7}$. As an intermediate product, $\mathrm{NaFeSi}_{2} \mathrm{O}_{6}$ shows a tendency to increase first and then decrease. This is due to the combination of $\mathrm{Na}_{2} \mathrm{CO}_{3}$ and $\mathrm{NaFeSi}_{2} \mathrm{O}_{6}$ to form more stable $\mathrm{Na}_{2} \mathrm{SiO}_{3}$ and $\mathrm{Fe}_{2} \mathrm{O}_{3}$, at the same time, the formation of $\mathrm{NaFeSi}_{2} \mathrm{O}_{6}$ also proves that when vanadium slag is roasted at $790{ }^{\circ} \mathrm{C}, 20 \% \mathrm{Na}_{2} \mathrm{CO}_{3}$ is appropriate. In the phase region 
of $\mathrm{NaFeSi}_{2} \mathrm{O}_{6}$, the main soluble sodium vanadate salts formed are $\mathrm{NaVO}_{3}$ and $\mathrm{Na}_{4} \mathrm{~V}_{2} \mathrm{O}_{7}$, which are consistent with the experimental results.

It can be seen that $\mathrm{Fe}_{2} \mathrm{SiO}_{4}$ in vanadium slag is transformed into insoluble substances such as $\mathrm{NaFeSi}_{2} \mathrm{O}_{6}$ (acmite) in the case of consumption of sodium salt. due to the limited content of sodium carbonate, it is difficult for conopyroxene to be retained in roasting slag. when leaching experiments are carried out, acmite is insoluble, so the leaching rate of silicon is low, which achieves the purpose of separation of silicon and vanadium. At the same time, from the effect of the addition of sodium carbonate on the leaching rate of silicon, it can be seen that the increase of sodium carbonate is beneficial to the leaching of silicon, which is consistent with the thermodynamic analysis in Figure $7 \mathrm{~b}$. When excessive sodium carbonate is added, the silicon-containing phase changes from conopyroxene sodium silicate, while sodium silicate is easily soluble in water, which increases the leaching rate of silicon. Therefore, in the case of excessive sodium carbonate, the migration mode of silicon in the whole process is as follows:

$$
\mathrm{Fe}_{2} \mathrm{SiO}_{4} \rightarrow \mathrm{SiO}_{2} \rightarrow \mathrm{NaFeSi}_{2} \mathrm{O}_{6} \rightarrow \mathrm{Na}_{2} \mathrm{SiO}_{3}
$$

\subsection{Precipitation of Vanadium by Calcification}

To prepare $\mathrm{CaV}_{2} \mathrm{O}_{6}$ and ensure the precipitation of vanadium under weak acid conditions, the reaction system must be within the range of the red dotted line in Figure 8 [18], so the $\mathrm{pH}$ of the precipitation of vanadium is $6.7 \pm 0.1$.

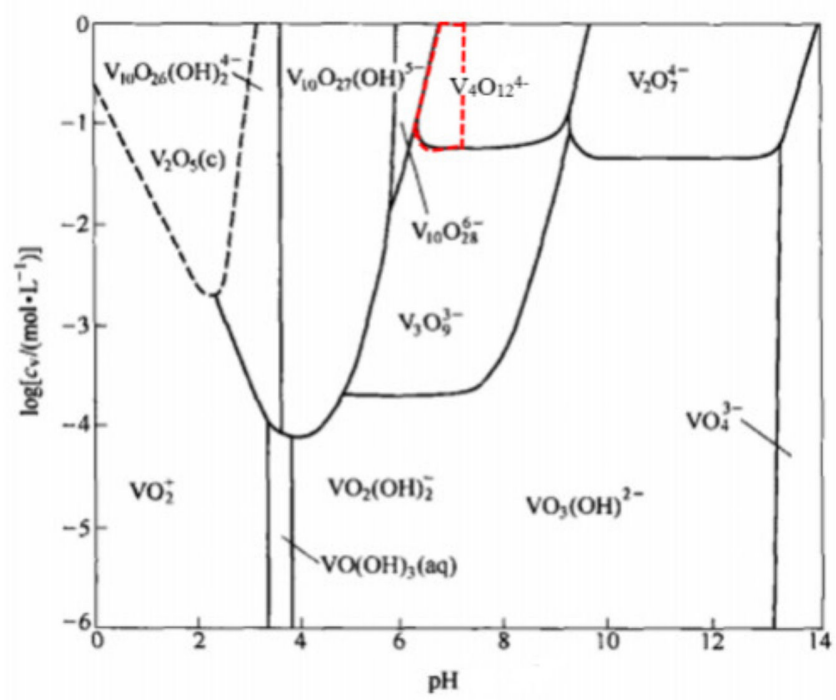

Figure 8. Morphology of pentavalent vanadate ions in aqueous solution.

The molar ratio of calcium to vanadium $\mathrm{N}$ refers to the effect of $\mathrm{n}(\mathrm{Ca}) / \mathrm{n}(\mathrm{V})$, on the precipitation rate of vanadium under the conditions of vanadium precipitation temperature $90{ }^{\circ} \mathrm{C}$, vanadium precipitation time $90 \mathrm{~min}$ and vanadium precipitation $\mathrm{pH} 6.7 \pm 0.1$. the effect of calcium-vanadium molar ratio $\mathrm{N}$ on vanadium precipitation ratio was investigated. The results are shown in Figure 9. It can be seen from the figure that with the increase of $\mathrm{N}$, the precipitation rate of vanadium increases gradually. When the ratio of calcium to vanadium is 0.45 , the precipitation ratio of vanadium is only $76.21 \%$. When the molar ratio of calcium to vanadium $\mathrm{N}$ increases to 0.6 , the precipitation ratio of vanadium reaches $95.03 \%$. With the continuous increase of $\mathrm{N}$, the precipitation ratio of vanadium increases very slowly. In the process of calcium precipitation of vanadium, the increase of the molar ratio of calcium to vanadate greatly promoted the positive precipitation of calcium vanadate. at the same time, under the acidic condition, it greatly inhibited the hydrolysis of $\mathrm{CaO}$ and increased the concentration of effective $\mathrm{Ca}$ in the solution system. Compared with precipitation at alkaline conditions of vanadium, the concentration of available calcium 
in the solution is lower, the reaction is slow and there are more impurities. Therefore, the suitable molar ratio of calcium to vanadium is 0.6 , and the vanadium concentration of the supernatant of precipitated vanadium under this condition is $0.41 \mathrm{~g} / \mathrm{L}$.

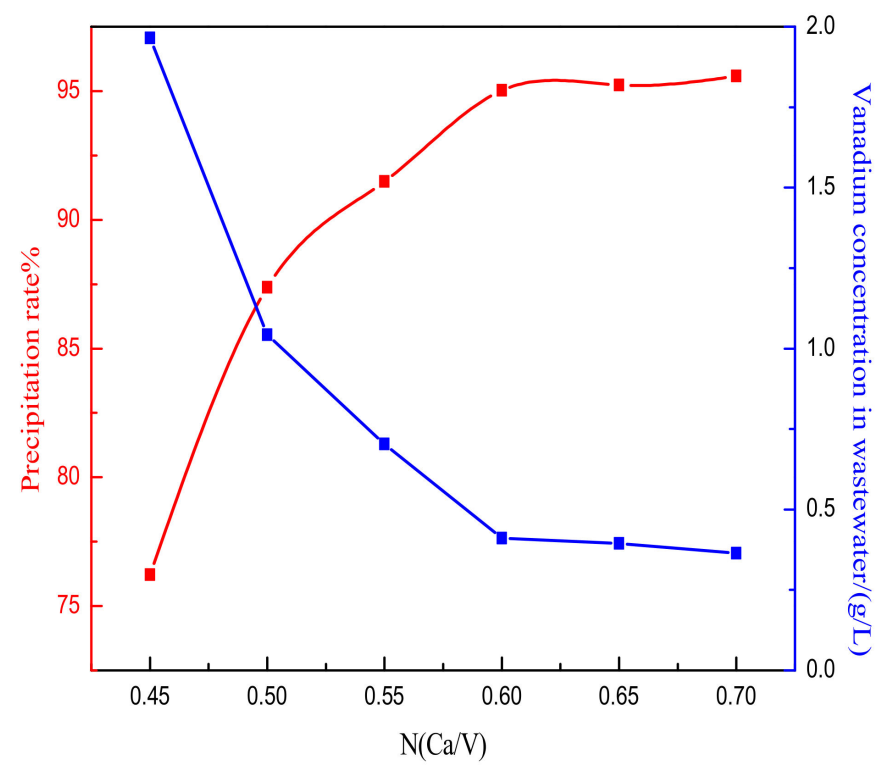

(a) Effect of molar ratio of calcium to vanadium on precipitation rate of vanadium

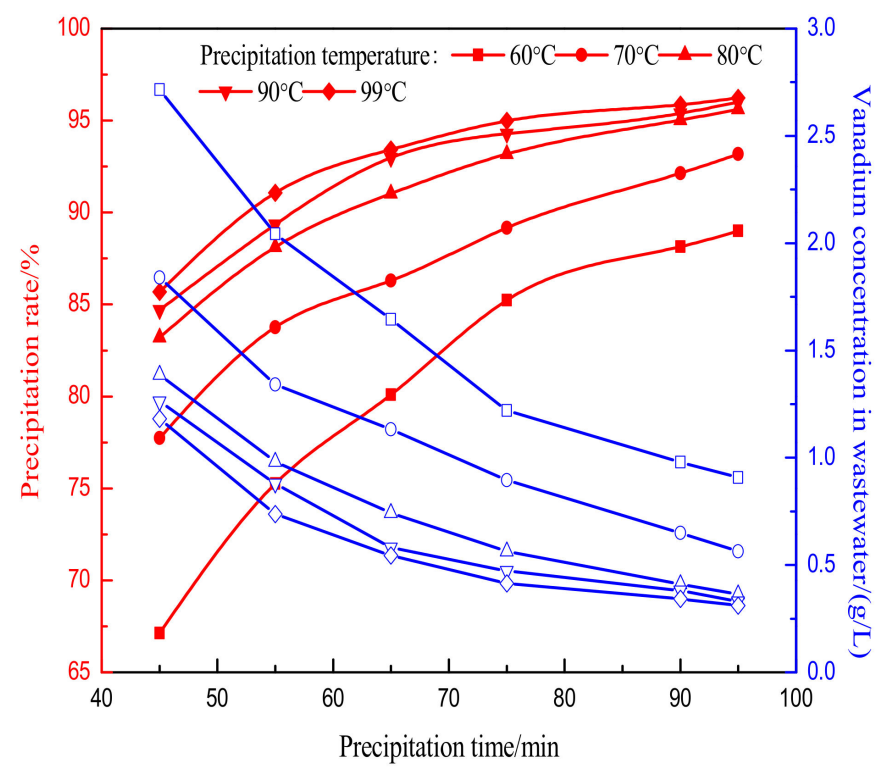

(b) Effect of precipitation temperature and time on precipitation rate of vanadium

Figure 9. The effects of $\mathrm{N}(\mathrm{Ca}) / \mathrm{n}(\mathrm{V})$, precipitation temperature, and precipitation time on the vanadium precipitation ratio and vanadium concentration in the vanadium wastewater.

It can be seen from the diagram that temperature and reaction time have a significant effect on the vanadium precipitation rate. Increasing vanadium precipitation temperature and reaction time can effectively increase the vanadium precipitation rate. When precipitation temperature is the same, increasing vanadium precipitation time can increase the vanadium precipitation rate. When precipitation time is the same, the higher the vanadium precipitation temperature is, the higher the vanadium precipitation rate is. 
The precipitation rate of vanadium at $80{ }^{\circ} \mathrm{C}, 90{ }^{\circ} \mathrm{C}$, and $99^{\circ} \mathrm{C}$ is much higher than that at $60{ }^{\circ} \mathrm{C}$ and $70{ }^{\circ} \mathrm{C}$, because the calcification reaction is endothermic, the reaction is positive, which is beneficial to the formation of vanadium precipitation. When the vanadium precipitation temperature is $60{ }^{\circ} \mathrm{C}$ and the vanadium precipitation time is $45 \mathrm{~min}$, the vanadium precipitation ratio is only $67.13 \%$, and the residual $\mathrm{V}$ concentration in the solution is $2.71 \mathrm{~g} 90 \mathrm{~min}$. When the vanadium precipitation time is $90 \mathrm{~min}$, the vanadium precipitation ratio increases to $88.14 \%$, while the residual vanadium concentration in the solution decreases to $0.97 \mathrm{~g} / \mathrm{L}$. When the vanadium precipitation temperature is $90{ }^{\circ} \mathrm{C}$ and the vanadium precipitation time is $45 \mathrm{~min}$, the vanadium precipitation ratio is $84.71 \%$, the concentration of residual vanadium in the supernatant of vanadium precipitation is $1.26 \mathrm{~g} / \mathrm{L}$ when the vanadium precipitation time is $90 \mathrm{~min}$, the vanadium precipitation ratio is $95.03 \%$, and the residual vanadium concentration in the vanadium precipitation supernatant is $0.41 \mathrm{~g} / \mathrm{L}$; when the vanadium precipitation temperature is $99^{\circ} \mathrm{C}$, the increase of vanadium precipitation rate will become very small.

Through this comparative analysis, it can be seen that time has a great influence on the vanadium precipitation rate when the vanadium is precipitated at low temperatures, and the effect of time on the vanadium precipitation rate will be greatly reduced when the temperature is beyond $80^{\circ} \mathrm{C}$. Therefore, the suitable temperature and time for depositing vanadium is $90^{\circ} \mathrm{C}$ and $90 \mathrm{~min}$.

\subsection{Kinetic Analysis of Vanadium Precipitation}

The process of calcium precipitation of vanadium is a process of isothermal crystallization, so the isothermal crystallization kinetics of vanadium precipitation can be described with Avrami kinetic model [19-21], the equation is as follows:

$$
\varphi=\varphi_{\infty}\left[1-\exp \left(-k t^{n}\right)\right]
$$

Among them, $\varphi$ is the volume fraction of calcium vanadate crystallized at $\mathrm{t}$ time (\%), $\varphi_{\infty}$ is the volume fraction of grains in the total sample for an infinitely long time) (\%), $k$ is the crystallization rate constant (min-n), $n$ is the Avrami index, which is related to the nucleation mechanism and growth mode. Avrami model assumes that the nuclei are irregularly distributed and each nucleus forms a grain.

Use $\eta$ to represent relative crystallinity, that is, $\eta=\varphi / \varphi_{\infty}$, then (6) can be rewritten as:

$$
1-\eta=\exp \left(-k t^{n}\right)
$$

Taking the logarithm of both sides of (4) we get:

$$
\ln [-\ln (1-\eta)]=\ln k+n \ln t
$$

Using $\ln [-\ln (1-\eta)]$ as the $y$-axis and $\ln t$ as the $x$-axis, draw the graph. According to the slope and intercept of the straight line obtained, the Avrami index $n$ and the reaction kinetic rate constant $\mathrm{k}$ can be obtained.

The Avrami index $n$ is theoretically an integer 1, 2, 3, etc., $n$ is 1, 2, 3 representing needle-shaped crystals, disc-shaped crystals, and spherical crystals, respectively. Practice has shown that most of the reaction crystallization processes are complex, will not form a single crystal grain, and the way of nucleation is not a single, so the Avrami index is generally a decimal number, usually not an integer.

The Avrami kinetic equation was used to fit the precipitation rate of vanadium at different temperatures and times in Figure 10. The relative crystallinity is the precipitation rate of vanadium. From Figure 10, it can be seen that the growth process of calcium vanadate crystals can be determined by Avrami at $60 \sim 80{ }^{\circ} \mathrm{C}$. The equation is well described, and the reaction kinetic parameters can be solved from the intercept and slope of each curve. It can be seen from Table 3 that as the temperature increases from $60{ }^{\circ} \mathrm{C}$ to $99{ }^{\circ} \mathrm{C}$, the crystallization rate constant increases from 0.035 to 0.16 , and the crystallization index 
decreases from 0.915 to 0.671 . When the temperature is $60^{\circ} \mathrm{C}$, the crystallization index is close to 1.0, and the crystal grows in one dimension and is a needle-like crystal. As the temperature increases, the crystallization will become complicated, and the crystallization index will gradually decrease. Under these temperature gradients, the crystallization index is low (less than 1), which may be a result of the combined effect of experimental deviation, temperature factors, and the complexity of the crystallization process, but it can be seen that the crystallization rate constant is more affected by temperature. Obviously, the higher the temperature, the higher the crystallization rate constant, which also proves that the calcification reaction is endothermic.

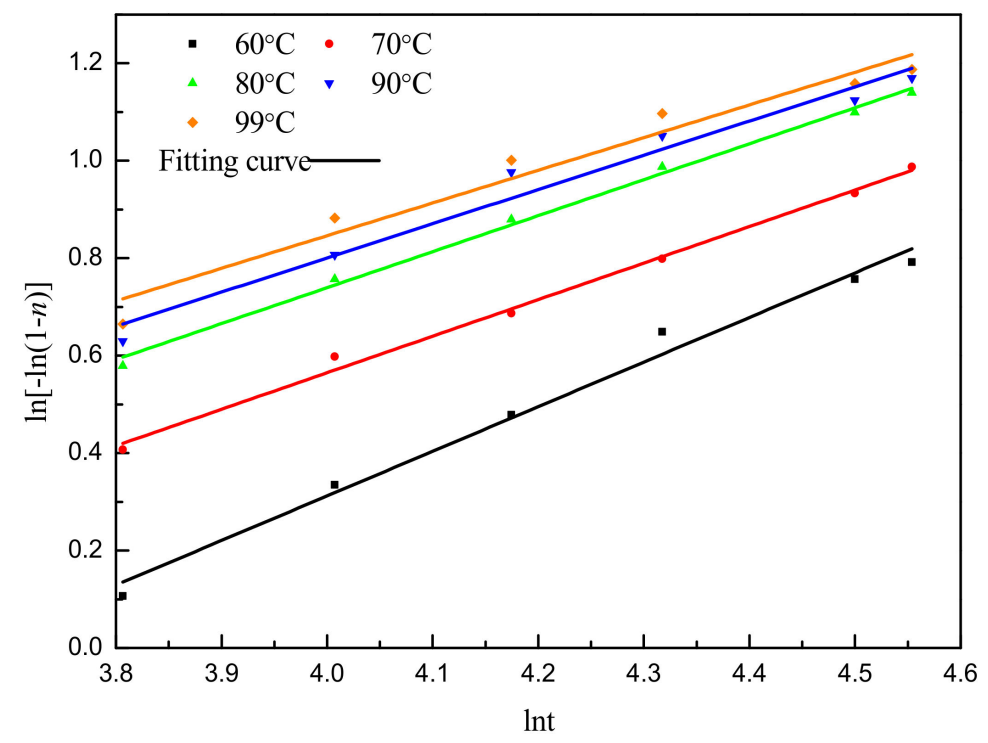

Figure 10. Relationship between $\ln [-\ln (1-\eta)]$ and $\ln$ at different temperatures.

Table 3. Dynamic parameters at different temperatures.

\begin{tabular}{ccccc}
\hline Temperature $/{ }^{\circ} \mathbf{C}$ & Pearson's r & R-Square & $\begin{array}{c}\text { Avrami Index } \\
\mathbf{n}\end{array}$ & $\begin{array}{c}\text { Crystallization } \\
\text { Rate Constant K }\end{array}$ \\
\hline 60 & 0.994 & 0.985 & 0.915 & 0.035 \\
70 & 0.997 & 0.994 & 0.750 & 0.082 \\
80 & 0.997 & 0.994 & 0.738 & 0.110 \\
90 & 0.985 & 0.964 & 0.702 & 0.135 \\
99 & 0.979 & 0.949 & 0.671 & 0.160 \\
\hline
\end{tabular}

According to the Arrhenius formula, the linear relationship between the reaction rate constant $K$ and temperature is as follows:

$$
\operatorname{Ln} K=\ln A-E_{a} /(R T)
$$

Plot $\ln K$ and $T^{-1}$ to get Figure 11, whose fitting equation is:

$$
\operatorname{Ln} K=11.818+5028.835 \mathrm{~T}
$$

By comparing Equations (9) and (10), we can get:

Pre-referential factor $\mathrm{A}=1.35 \times 10^{5}$, apparent activation energy Ea $=41.81 \mathrm{~kJ} / \mathrm{mol}$.

The phase and surface morphology of the calcium vanadate product under the conditions of a reaction time of $90 \mathrm{~min}$, a reaction temperature of $90^{\circ} \mathrm{C}$, and a calcium-vanadium molar ratio of 0.6 are shown in Figures 12 and 13. 


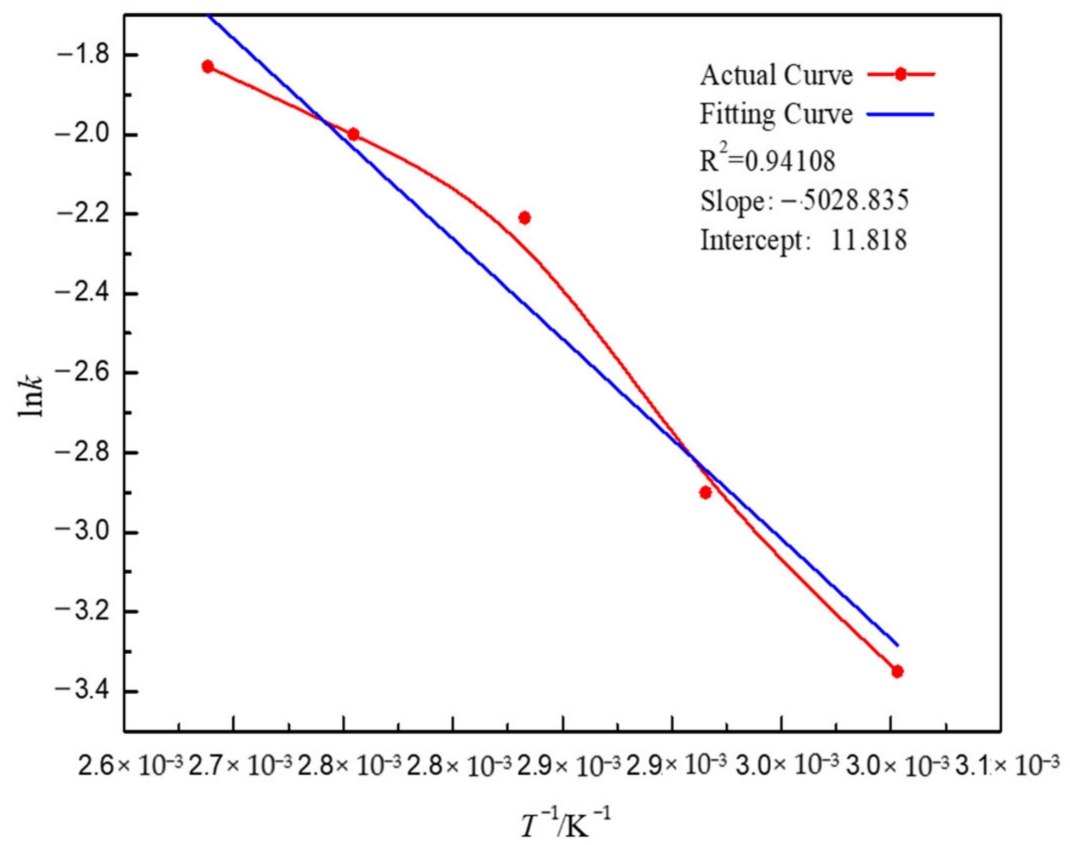

Figure 11. Relationship between $\ln K$ and $T^{-1}$.

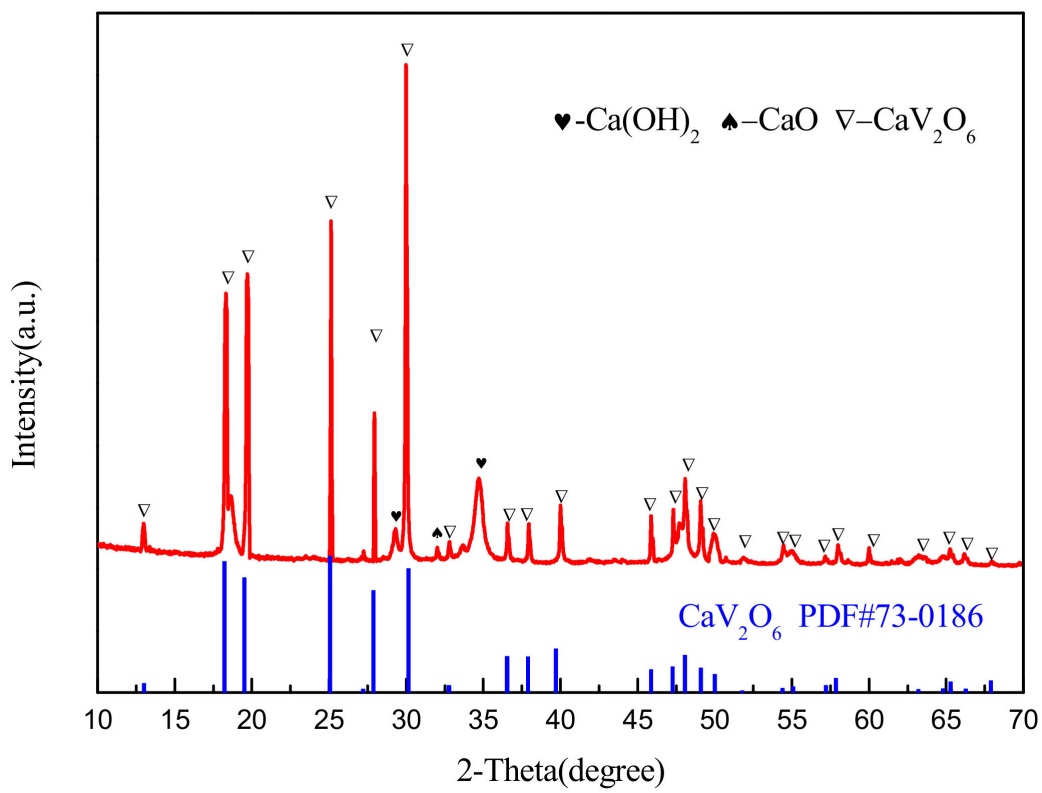

Figure 12. XRD pattern of calcification products.

It can be seen from Figure 12 that the precipitation products are mainly $\mathrm{CaV}_{2} \mathrm{O}_{6}$ and a small amount of $\mathrm{CaO}$ and $\mathrm{Ca}(\mathrm{OH})_{2}$. From Table 4, it is calculated that $\mathrm{CaV}_{2} \mathrm{O}_{6}$ in the calcium method product accounts for about $95.69 \%$, and the molar ratio of calcium to vanadium is 0.58 , which is greater than that of $\mathrm{CaV}_{2} \mathrm{O}_{6}$.

Table 4. Chemical composition of calcific product.

\begin{tabular}{lccccc}
\hline Component & $\mathbf{C a}$ & $\mathrm{V}$ & $\mathrm{CaO}$ & $\mathrm{V}_{\mathbf{2}} \mathbf{O}_{\mathbf{5}}$ & $\mathrm{Ca}: \mathbf{V}(\mathbf{m o l})$ \\
\hline Content $(\%, w \mathrm{t})$ & 19.66 & 43.92 & 20.61 & 78.41 & 0.56 \\
\hline
\end{tabular}

Figure 13 shows the microscopic morphology of the precipitated product. It can be seen from Figure 13 that the synthesized $\mathrm{CaV}_{2} \mathrm{O}_{6}$ crystals are dendritic needle-like crystals. 
Combined with thermodynamic and kinetic analysis, it can be seen that the formation of calcium vanadate is dependent on other impurity points. The nucleus grows up, and this non-uniform nucleation point should be calcium oxide or calcium hydroxide. At the beginning of the reaction, even under acidic conditions, calcium oxide combines with water to form a large amount of $\mathrm{Ca}(\mathrm{OH})_{2}$. Calcium provides nucleation sites for the formation of calcium vanadate. As the reaction time increases, the action of calcium hydroxide and hydrochloric acid in the solution is "eroded", and as the outer $\mathrm{Ca}^{2+}$ is "eroded", the internal $\mathrm{Ca}^{2+}$ gradually Migrate to the surface of the formed calcium vanadate, and further contact with the Vanadate ion in the solution, the calcium vanadate crystals will continue to grow. Because the reaction of preparing calcium vanadate by calcium precipitation of vanadium is an endothermic reaction, it tends to grow higher. As shown in Figure 13, the morphological structure of calcium vanadate is needle-like, and it is attached to the nucleation site to expand in three dimensions. The energy-dispersive X-ray spectroscopy (EDS) matched with the scanning electron microscope measured the elemental composition of the sample. The $\mathrm{Ca}, \mathrm{V}$ and $\mathrm{O}$ element signal peaks appeared in the spectrum. The calculated average $\mathrm{Ca} / \mathrm{V}$ ratio was 0.521 , which is close to the atomic ratio of calcium to vanadium in $\mathrm{CaV}_{2} \mathrm{O}_{6}$. The theoretical stoichiometric value of the chemical formula.

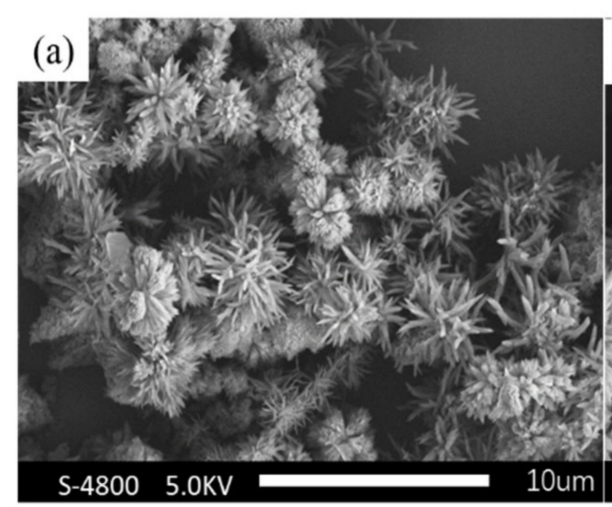

(b)
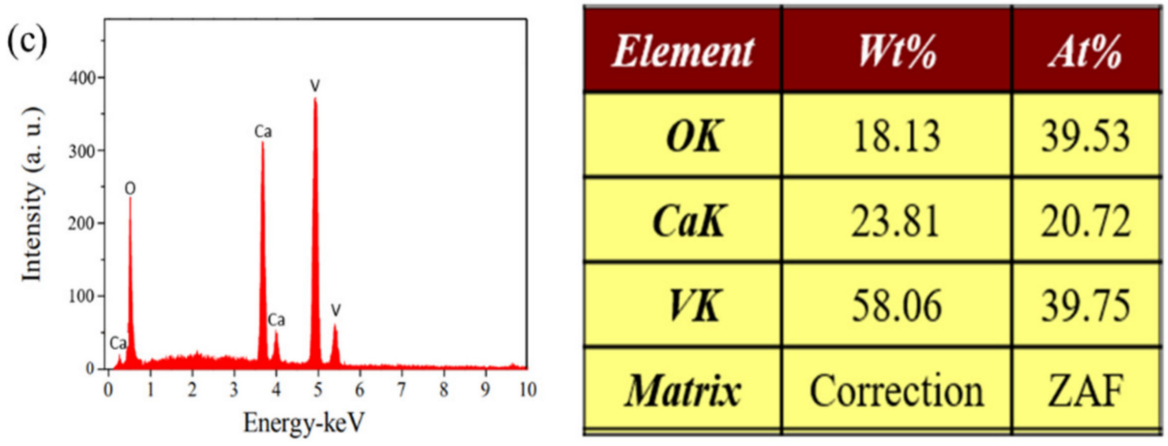

Figure 13. Surface morphology and energy spectrum analysis of calcification products $\left((\mathbf{a}, \mathbf{b}) \mathrm{CaV}_{2} \mathrm{O}_{6}\right.$ surface morphology under different magnifications; (c) analysis of the energy spectrum points in the Figure 13(b)).

\section{Conclusions}

A simple schematic diagram of the whole process is shown in Figure 14. The main conclusions of this research are as follows: The experimental study of vanadium slag singlefactor sodiumization roasting shows that with the increase of the roasting temperature and the extension of the roasting time, the vanadium leaching rate increases first and then decreases; during the roasting process, increasing the amount of $\mathrm{Na}_{2} \mathrm{CO}_{3}$ within a certain range can be effective Improve the leaching rate of vanadium, but if it is too high, it will decrease the leaching rate of vanadium. The best calcination conditions under the experimental conditions are calcination time $120 \mathrm{~min}$, calcination temperature $790{ }^{\circ} \mathrm{C}$, and $\mathrm{Na}_{2} \mathrm{CO}_{3}$ addition amount is $20 \%$. 


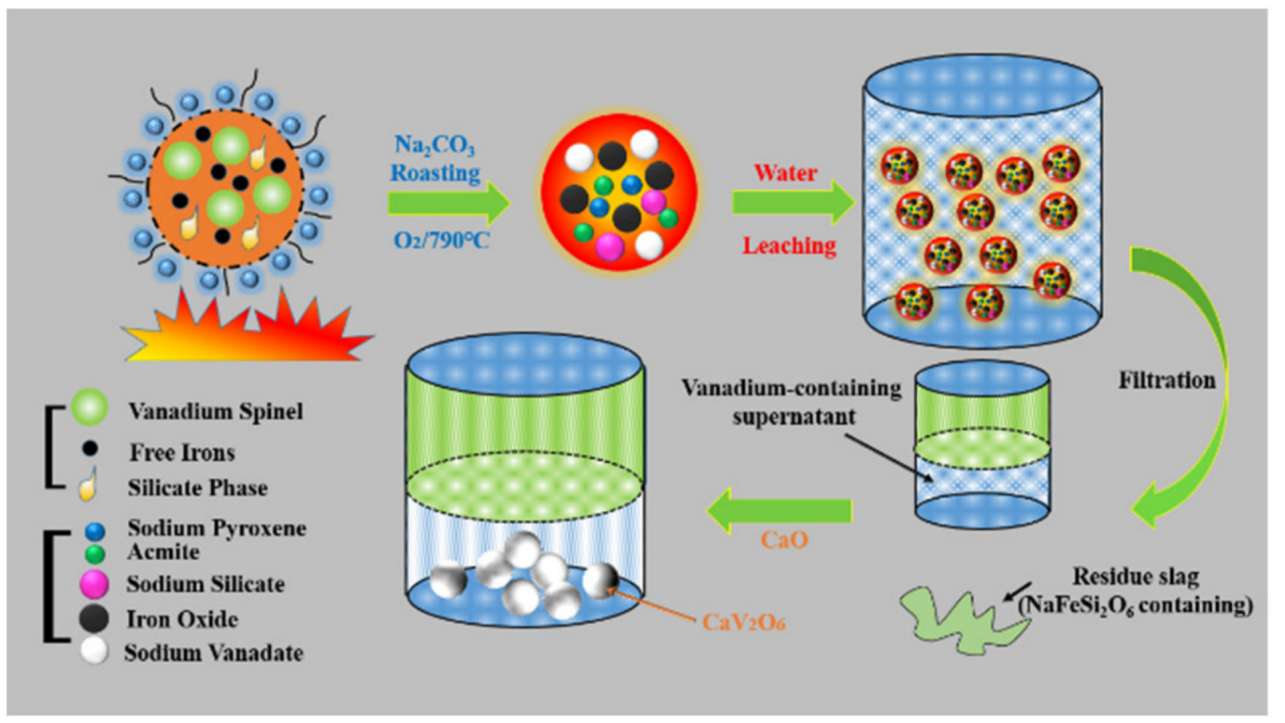

Figure 14. Process diagram.

The single-factor leaching experiment of vanadium slag roasting clinker shows that the leaching rate of vanadium increases with the increase of leaching temperature and leaching time, and it first increases and then decreases with the increase of solid-liquid ratio; vanadium leaching The process is controlled by diffusion and conforms to the shrinking core model with reduced particle size. The optimum leaching conditions were as follows: leaching temperature $90^{\circ} \mathrm{C}$, leaching time $90 \mathrm{~min}$, leaching liquid-solid ratio 5:1, and vanadium leaching solution can be used for calcification and vanadium deposition without purification.

After sodium roasting-water leaching of vanadium slag, vanadium and silicon can be effectively separated. Under the optimum roasting and leaching conditions, the leaching rate of vanadium is $89.54 \%$, and the leaching rate of silicon is $1.96 \%$, which achieves the effective separation of vanadium and silicon. Vanadium combines with sodium to form sodium vanadate. Silicon is easy to combine with iron, sodium, and titanium to form acmite and sodium pyroxene.

The experimental study on calcium precipitation of vanadium shows that the precipitation time of vanadium is $90 \mathrm{~min}$, the temperature of precipitation of vanadium is $90{ }^{\circ} \mathrm{C}$, the molar ratio of calcium to vanadium is 0.6 , the best precipitation ratio of vanadium is $95.03 \%$, and the concentration of residual vanadium in the supernatant of precipitated vanadium is $0.41 \mathrm{~g} / \mathrm{L}$. The process of calcium precipitation of vanadium can be described by Avrami isothermal crystallization kinetic model. Under the experimental conditions, the apparent activation energy of the reaction is $41.81 \mathrm{~kJ} / \mathrm{mol}$. the main phase of the calcification product is $\mathrm{CaV}_{2} \mathrm{O}_{6}$, which is a dendritic needle crystal.

Author Contributions: Conceptualization, C.L. and H.Z.; methodology, C.L.; software, Y.T.; validation, X.W., M.T. and H.L.; formal analysis, C.L.; investigation, Y.L.; resources, C.L.; data curation, Y.L.; writing—original draft preparation, C.L.; writing—review and editing, C.L.; visualization, Y.L; supervision, Y.T; project administration, Y.L.; funding acquisition, Y.L. All authors have read and agreed to the published version of the manuscript.

Funding: This research was funded by National Natural Science Foundation of China, grant number 51774142 .

Institutional Review Board Statement: Not applicable.

Informed Consent Statement: Not applicable.

Data Availability Statement: The data presented in this study are contained in this article. 
Acknowledgments: The study is financially supported by the National Natural Science Foundation of China (Project No. 51774142).

Conflicts of Interest: The authors states that there is no conflict of interest.

\section{References}

1. Zhang, J.H.; Zhang, W.; Li, Z.L.; Gu, S.Q. Mechanism of vanadium slag roasting with calcium oxide. Int. J. Miner. Process. 2015, 138, 20-29. [CrossRef]

2. Peng, H. A literature review on leaching and recovery of vanadium. J. Environ. Chem. Eng. 2019, 7, 103313. [CrossRef]

3. Hao, Y.-L.; Li, S.-J.; Yang, R. Biomedical titanium alloys and their additive manufacturing. Rare Met. 2016, 35, 661-671. [CrossRef]

4. Liang, Z.; Sun, Z.; Zhang, W.; Wu, S.; Chang, H. The effect of heat treatment on microstructure evolution and tensile properties of selective laser melted Ti6Al4V alloy. J. Alloys Compd. 2019, 782, 1041-1048. [CrossRef]

5. Zhao, Y.; Wang, W.; Zhang, Y.; Song, S.; Bao, S. In-situ investigation on mineral phase transition during roasting of vana-diumbearing stone coal. Adv. Powder Technol. 2017, 28, 1103-1107. [CrossRef]

6. Zhang, Y.-M.; Bao, S.-X.; Liu, T.; Chen, T.-J.; Huang, J. The technology of extracting vanadium from stone coal in China: History, current status and future prospects. Hydrometallurgy 2011, 109, 116-124. [CrossRef]

7. Wen, J.; Jiang, T.; Arken, S. Selective leaching of vanadium from vanadium-chromium slag using sodium bicarbonate solution and subsequent in-situ preparation of flower-like VS2. Hydrometallurgy 2020, 198, 105498. [CrossRef]

8. Liu, C.; He, X.J.; Zhang, J. Situation and Prospects of Concentration of Vanadium Resources. Miner. Eng. 2014, 12, 18-20.

9. Cai, J.; Ba, L. New technology of extraction vanadium from stone coal. Conserv. Utiliz. Miner. Resour. 1993, 5, 30-33.

10. Moskalyk, R.; Alfantazi, A. Processing of vanadium: A review. Miner. Eng. 2003, 16, 793-805. [CrossRef]

11. Wen, J.; Jiang, T.; Liu, Y.; Xue, X. Extraction Behavior of Vanadium and Chromium by Calcification Roasting-Acid Leaching from High Chromium Vanadium Slag: Optimization Using Response Surface Methodology. Miner. Process. Extr. Met. Rev. 2018, 40, 56-66. [CrossRef]

12. Wen, J.; Jiang, T.; Xu, Y.; Cao, J.; Xue, X. Efficient extraction and separation of vanadium and chromium in high chromium vanadium slag by sodium salt roasting-(NH4)2SO4 leaching. J. Ind. Eng. Chem. 2019, 71, 327-335. [CrossRef]

13. Gao, F.; Yan, W.B.; Li, Y.J.; Shi, M.L.; Zhou, Z.X.; Huang, D.D. Preparation of ammonium metavanadate and kinetics of vanadium precipitation. J. Chin. Ceram. Soc. 2011, 9, 1423-1427.

14. Li, Z.J.; Pang, X.T.; Liu, C.R. Study on process conditions of weak acid vanadium precipitation by salt. J. Zhengzhou Univ. 1994, 26, 83-86.

15. Yuan, Z.F.; Qian, J.S.; Shi, Y.H. Reduction and direct alloying of calcium vanadate. Iron Steel 1992, 2, 20-24. [CrossRef]

16. Tiffert, T.; Lew, V.L. Kinetics of inhibition of the plasma membrane calcium pump by vanadate in intact human red cells. Cell Calcium 2001, 30, 337-342. [CrossRef]

17. Jiang, T.; Wen, J.; Zhou, M.; Xue, X. Phase evolutions, microstructure and reaction mechanism during calcification roasting of high chromium vanadium slag. J. Alloys Compd. 2018, 742, 402-412. [CrossRef]

18. Zhou, X.-J.; Chang, W.; Li, M.-T.; Qiu, S.; Li, X.-B. Thermodynamics of vanadium-sulfur-water systems at 298 K. Hydrometallurgy 2011, 106, 104-112. [CrossRef]

19. Melvin, A. Kinetics of Phase Change. I General Theory. J. Chem. Phys. 1939, 7, 1103-1112.

20. Melvin, A. Kinetics of Phase Change. II Transformation-Time Relations for Random Distribution of Nuclei. J. Chem. Phys. 1940, 8 , 212-224.

21. Melvin, A. Kinetics of Phase Change. III* Granulation, Phase Change, and Microstructure. J. Chem. Phys. 1941, 9 , 177. 